\title{
Jane Austen y C. S. Lewis: de la literatura al cine. Análisis de transposición
}

\author{
Recibido: 02 de diciembre de 2015 \\ Aceptado: 04 de agosto de 2016 \\ Publicado: 30 de noviembre de 2016
}

\author{
Mercedes Sarapura Sarapura \\ msarapuras@usmp.pe
}

Universidad de San Martín de Porres (Perú)

Resumen: Esta es una propuesta de análisis de transposición de la literatura al cine de la novela Orgullo y Prejuicio, de Jane Austen, y del ensayo Una pena observada, de C. S. Lewis. El primer propósito en ambos casos es ahondar en los nuevos aportes de la última versión cinematográfica de la novela de Austen, así como en las características y cualidades de la versión fílmica del cuaderno de anotaciones de C. S. Lewis, a partir de las contribuciones teóricas de autores como Gerard Genette, Georffrey Wagner, Brian Mcfarlane, entre otros.

El segundo objetivo se orienta al reconocimiento del intercambio entre el lenguaje cinematográfico y literario como un proceso representativo de la sociedad actual. El hecho de que las adaptaciones (históricamente vistas con gran escepticismo) sean ahora continuamente realizadas y acogidas por el público, insta a una revisión y profundización de los estudios que se han hecho al respecto con el fin de conocer la situación actual de la relación existente entre cine y literatura, sus posibilidades creativas, las expectativas de las audiencias, los prejuicios y recelos de los expertos, etc.

Palabras clave: Transposición, cine, literatura, adaptación, C. S. Lewis, Jane Austen.

Abstract: The following is a proposal of an analysis of the transposition of literature to film of the novel Pride and Prejudice by Jane Austen and the essay A Grief Observed by C. S. Lewis. The first aim in both cases is to delve into the new contributions of the latest film version of Austin's novel and the qualities and characteristics of the film version of the C.S. Lewis note pad, based on the theoretical contributions of such authors as Gerard Genette, Geoffrey Wagner, Brian Mcfarlane, among others. 
The second purpose is geared to the recognition of the exchange between film and literary language as a representative process of today society. The fact that the adaptations, historically seen with great skepticism, are now continually made and welcomed by the public, calls for a review and deepening of the studies made on that matter in order to know the current situation of the relationship between film and literature, its creative possibilities, audience expectations, prejudices and misgivings of experts, etc.

Key words: Transposition, Film, Literature, Adaptation, C. S. Lewis, Jane Austen.

\section{Introducción}

La literatura ha incursionado en la dimensión audiovisual desde los inicios del cine. En la actualidad, esta tendencia es más frecuente como consecuencia del desarrollo de las nuevas tecnologías de la comunicación, las cuales han intensificado el tránsito e intercambio de contenidos de un lenguaje artístico a otro, lo que ha supuesto el arribo de nuevas experiencias y significaciones. Los resultados, acogidos por las audiencias, son exploraciones que prueban la maleabilidad de las tramas más allá de los lenguajes artísticos o de las épocas.

Dos razones serían las que impulsan las transferencias de lenguaje en la actualidad; por un lado, el interés de las productoras cinematográficas por adaptar obras literarias de amplia acogida (best-sellers) que repliquen ese éxito en taquilla y así evitar el riesgo de presentar una obra nueva. Tal fue el caso de la saga de Harry Potter, basada en las novelas de J. K. Rowling, adaptadas por Heyday Films y Warner Bros, en el que la autora asesoró los guiones para garantizar fidelidad a sus novelas. Por otro lado, la perspectiva cinematográfica, que en muchos casos no sigue fielmente los rasgos de la novela, sino que toma algunos de sus elementos para modificarla y reinventarla, creándose así una obra casi nueva. Es el caso de Alfred Hitchcock, cuyas películas estuvieron basadas en novelas y cuentos ( $c f$. Rebatta, 2015).

Ahora bien, el desplazamiento de los contenidos (de un soporte artístico a otro) ha sido de interés constante para la teoría literaria, la crítica cinematográfica, la comunicación y la semiótica. El cine (convertido en poderoso espejo social) nació como medio de comunicación de masas con capacidad para impulsar la ficción literaria y llevarla a los grandes públicos, a riesgo de transformarla parcial o radicalmente; lo que significaría un cambio favorable (o no) para el lenguaje cinematográfico y para la literatura (según como se mire), que a su vez constituirá el punto de partida para estudiar el proceso de cambios de soporte de mensaje y su impacto en los públicos, aspectos que atañen a la comunicación.

La transición (que es una característica clave en la era digital, el ir y venir y el estado omnisciente) constituyen un complejo universo cuando se habla de adaptaciones. Las reconstrucciones, el cruce de un soporte tecnológico a otro y de un lenguaje artístico a otro, proponen una forma de enriquecimiento del arte, que encuentra su más elevada 
trascendencia en su capacidad de moldear los imaginarios sociales, por la forma en que impactan a las audiencias, ya que sus idearios perviven a través de las obras literarias y cinematográficas, que ahora mutan y se transforman con la ayuda de una tecnología mucho más accesible. Por todo ello, resulta importante determinar cómo se dan esos cambios y transformaciones que enseguida se reflejan en los estilos de vida, creencias, aspiraciones, etc. que a su vez regresan otra vez a los medios, como un proceso de retroalimentación indefinido. Este hecho y los contrastes entre las formas de expresión de un arte y otro constituyen la profunda importancia de las transposiciones y su utilidad.

Se ha dicho que, desde sus inicios, el cine ha tenido como fuente a la literatura, pero también es verdad que el cine retribuyó a esta con la concretización de escenarios y personajes ya no solo para los lectores, sino para un público mucho más amplio. En la actualidad, los imaginarios de amor, felicidad y éxito se sostienen también por la simbiosis entre cine y literatura, que mantiene vigentes a autores como Jane Austen a través de reiteradas transposiciones de sus obras al séptimo arte.

\section{Cine y literatura}

Se ha debatido lo suficiente sobre la rivalidad existente entre cine y literatura, así como sobre la presunta inferioridad artística del cine. No obstante, lo que aquí se quiere subrayar es el reconocimiento del cine como séptimo arte, carente de toda inferioridad, debido a la condición incomparable de dos lenguajes complejos que se encuentran ineludiblemente vinculados desde los inicios del cine.

La literatura ha sido fuente inagotable del cine, sin quedar este último subyugado, sino que (haciendo eco de contenidos literarios elevados) ha llevado a los grandes públicos a experimentar con dichos contenidos de otras maneras, propiciándose una valiosa complementariedad. D. W. Griffith reconoce la herencia estructural que recibió de la narrativa, refiriéndose concretamente a Charles Dickens. Deteniéndonos en ese cineasta, Eisenstein (1977: 200) recoge el incidente que pasó el director cuando los encargados de la Biograph Company le increpaban su propósito de presentar dos escenas que ocurrían a kilómetros de distancia con la técnica del montaje paralelo': 'La gente no va a entender nada', le dijeron; a lo que Griffith respondió: 'Y bien, ¿no escribe así Dickens?', 'Sí, pero Dickens; eso es escribir novelas, es diferente'; 'No tanto, estas son historias fotografiadas, no es tan diferente"".

Por su parte, Sánchez Noriega ( $c f$. 2001: 66) sostiene que el cine atraviesa tres dimensiones en sus orígenes: a) primero pasa por una etapa documental que corresponde a las vistas de los hermanos Lumiere, en la que se constituye como instrumento que trasmite pequeños extractos de la realidad cotidiana; b) luego, la dimensión espectacular, desarrollada por

1 Método de composición que tiene como base la alternancia de unidades opositivas (Peña-Ardid, 2009: 137). 
Méliès $^{2}$ y la escuela de Brighton que se basan en los espectáculos de feria en el que interviene el trucaje y el ilusionismo; y finalmente $c$ ) la dimensión narrativa, que alcanza su madurez con los trabajos de David Griffith. Asimismo, sustenta que el cine (en cuanto narración) es vástago de la tradición literaria; en cuanto representación, del teatro; $\mathrm{y}$ en cuanto captación fotoquímica de la realidad, de la fotografía.

Uno de los aspectos importantes a resaltar son las comparaciones realizadas entre los sistemas narrativos del cine y la literatura. En la novela, la descripción de una voz omnisciente ayuda a conocer y definir los espacios y atmósferas donde dialogan y actúan los personajes; mientras que en el cine se presenta una historia narrada por las imágenes, es decir, el aparato enunciativo (que es la cámara) son los ojos que observan y, a su vez, conducen los cientos de miradas que recorren cada escena y secuencia. De esta forma, los planos, sus duraciones, los movimientos de cámara, los ángulos (además del sonido, los silencios, la música, las luces y sombras) enuncian más allá de lo que los personajes dicen.

De esta manera, el cine se hace mucho más valioso artísticamente, en la medida que aumenta y complejiza su carácter descriptivo (con la conjunción de la atmósfera) y el ritmo narrativo, los cuales determinan el tono ficcional de la película más allá de las palabras, pero sin prescindir de ellas. La atmósfera hace referencia a lo que es perceptible (aunque intangible) que comprende las características que reúne un determinado lugar, el momento (el día, la noche, las horas) y el estado anímico de los personajes. El ritmo narrativo alude a la variedad de planos y ángulos, así como a la frecuencia, rapidez o lentitud con que se alternan.

No obstante, la imagen no lo es todo para el cine, como la palabra no lo es para la literatura. La narración de espacios y atmósferas la realiza el cine basándose en la cámara. No obstante, la palabra se haya presente desde el cine mudo, a través de textos en los fotogramas o carteles en los escenarios tal como ocurre con la realidad; y por supuesto, en los diálogos de los personajes. Mientras que en literatura, la presencia tácita de las imágenes pueblan la imaginación del lector.

Otro aspecto a destacar en la estructura narrativa de ambos lenguajes artísticos es la naturaleza física de sus espacios, es decir, el soporte de la novela es el libro, cuyo límite de páginas es inagotable $u$ ofrece mayor margen, pero que precisa de un orden que fracture la narración en capítulos y apartados. En el cine, el límite de duración lo establece el tiempo real, no más de tres horas; aunque luego se trate de una saga. Posiblemente, esta condición hace que en las adaptaciones se advierta una obligada síntesis de la historia. Por ejemplo, en la literatura, el trasfondo social y cultural (sobre las que tienen lugar las interrelaciones humanas que a su vez resultarán influyentes en el curso de una determinada historia y en las decisiones de los personajes) pueden llegar a ser tan complejas e importantes como la historia de amor en ciernes, mientras que para el cine será mucho más importante destacar el romance, aunque pierdan vigor las circunstancias que rodean al vínculo afectivo entre los protagonistas.

2 En 1900, Méliès hizo la primera adaptación de La Cenicienta al cine; y en 1902, Viaje a la luna, basada en la novela De la Tierra a la luna, de Julio Verne, y Los primeros hombres en la luna, de H. G. Wells. 
Esta ha sido una de las causas de acusación de inferioridad artística al cine, porque pondera un solo elemento entre tantos otros que sí encuentran lugar en la novela; y además porque (de entre todos esos elementos) tiende a preferir la historia de amor. Martín Barbero (1987: 161) sostiene que "a través del folletín el cine recibe en herencia el melodrama", que lo transforma otra vez en espectáculo popular que moviliza las grandes masas. El autor considera que hay dos géneros en los que el cine norteamericano ha basado su universalidad: la invención del western y la recreación del melodrama (ibídem).

Claro que es el director quien decide con qué elementos de la trama original ha decidido quedarse y esto estaría acorde con la categoría de comentario que define Wagner, como aquella adaptación que resulta de la interpretación propia de la novela que hace el realizador (ápud Carvajal, 2011: 48), que se diferencia de la propuesta del escritor, tal como ocurre con la película Del amor y otros demonios (2010), de la directora Hilda Hidalgo, en la que la realizadora ubica como centro de la película el problema de la enfermedad de la rabia y la superstición, dejando de lado otros elementos de la novela (ibídem).

Es a partir de este criterio que Rebatta (2015) exalta el valor artístico y autónomo del cine porque crea un contexto, perfila la psicología de los personajes y ahonda en conflictos personales que no existen en la obra literaria, tal como experimentó en su cortometraje Almas solas (2001), una libre adaptación de la novela corta Fabla salvaje de César Vallejo. “En sus 'cuatro ideas', el guionista Lewis Herman llama 'idea leída' a esta que nos asalta al momento de leer algún texto, es decir, nos puede interesar sólo un acontecimiento de la obra leída, tal vez un capítulo o solo un párrafo atractivo y esta impresión genera una idea para el film. En Blow up, Michelangelo Antonioni rescata del cuento Las barbas del diablo, de Julio Cortázar, la anécdota central: el personaje que fotografía una situación callejera para luego de revelar y ampliar la foto, descubra algo que no vio en el inicio".

Finalmente, es preciso observar que el aporte cinematográfico se encuentra sustancialmente en sus dos instancias de elaboración. La primera de ellas durante el rodaje (etapa en la que se determinan con precisión los ángulos y planos de cada escena y secuencia) y después en la edición, momento en el que se articulan definitivamente dichas escenas y secuencias.

\section{Teorías de análisis y modelos de transposiciones}

Bermúdez (2008: 2) señala que la transposición es uno de los rasgos característicos de la sociedad actual al punto de convertirse en "la operación socio-semiótica que define zonas claves de la cultura contemporánea". Por su parte, Steimberg recuerda que la semiótica es "el estudio de los modos de producción de la significación o de producción de sentido" (ápud TV Pública Argentina, 2013). A partir de este concepto, el cine y la literatura son modos de producción de sentido independientes y la transposición propicia uno más bien híbrido que actualmente es asimilado por los públicos de manera creciente.

Para aquilatar la importancia del fenómeno de la transposición es preciso tener conciencia de la importancia de sus significaciones en la cultura en la que tiene lugar. El hecho de 
que una sociedad busque la redefinición o reconstrucción continua de contenidos de unos lenguajes a otro posiblemente sea indicio de la interactividad de sus receptores especialmente interesados en los cambios de formas más que de contenidos. Por ello, es necesaria una comprensión de los modos que tiene el cine para producir significados y de los modos que tiene la literatura para hacerlo y compararlos: no para determinar superioridades, sino para conocer el contraste entre un universo de significación y otro, así como sus niveles de complementariedad. Por ello, en este análisis se ha propuesto como base los aportes teóricos de Gerard Genette, Charles Pierce y otros importantes teóricos.

En vista que ayudará a comprender esencialmente la complejidad de una transposición, se toma como punto de partida la definición de "signo" de Pierce (1974: 22), quien al denominarlo representamen, afirma que "es algo que, para alguien, representa o se refiere a algo en algún aspecto o carácter. Se dirige a alguien, esto es, crea en la mente de esa persona un signo equivalente, o, tal vez, un signo aún más desarrollado. Este signo creado es lo que yo llamo el interpretante del primer signo". En base a ello determina las relaciones triádicas de comparación ${ }^{3}$, funcionamiento ${ }^{4}$ y de pensamiento ${ }^{5}$ que servirán como guía para analizar las transposiciones propuestas.

Para Genette (cf. 1989: 10) existen cinco prácticas transtextuales: la intertextualidad, el paratexto, la metatextualidad, la hipertextualidad y la architextualidad. El análisis de los cambios de soporte correspondería a la hipertextualidad, que es el resultado de una relación entre un texto B (que llama hipertexto) y un texto A al que denomina "hipotexto". Ahora bien, dicha relación entre hipotexto e hipertexto puede ser de transformación o de imitación. La transformación comprende tres tipos de regímenes ${ }^{6}$ : parodia (lúdico), travestimiento (satírico) y transposición ${ }^{7}$ (serio); mientras que la imitación comprende los regímenes "pastiche" (lúdico), "imitación satírica" (satírico) e "imitación seria" (serio). La diferencia entre transformación e imitación consiste en que la transformación supone un cambio de estilo, mas no de tema; mientras que la imitación supone un cambio de tema pero no de estilo.

3 Apunta a la naturaleza misma del signo: "cualisigno", que representa una cualidad; "sinsigno", que representa una cualidad encarnada; "legisigno", que representa las leyes (cf. Pierce, 1974: 25).

4 Se refiere a la relación entre el signo y el objeto. El ícono, cuando el signo que es similar al objeto; el índice, cuando el signo tiene una relación real con el objeto; finalmente, el símbolo, que es un signo carente de relación directa con el objeto (ibidem).

5 Cuya naturaleza son las leyes. El primero de ellos es el rhema, signo que representa una información en sí misma; luego, el dicente que es el signo que aporta características concretas de algo; y finalmente, el argumento, cuando el signo aporta un razonamiento inductivo o deductivo (ibidem).

6 Genette (1989: 42) sustituye el término "función" por régimen: "Por parecerme un término más flexible y menos drástico, pero sería ingenuo imaginar que se pueda trazar una frontera estanca entre estas grandes diátesis del funcionamiento sociopsicológico del hipertexto".

7 En un nivel funcional, Genette trata de ser más preciso y luego de reconocer en la parodia un carácter jocoso (aunque no agresivo, como sí sucede con el travestimiento) crea un nuevo espacio para las transformaciones serias: las transposiciones (ibídem: 41). 
Christian Metz se apoya en la lingüística estructural para estudiar la semiótica aplicada al cine al que define como un lenguaje sin lengua, "el cine es ante todo habla. Todo en él es aseveración. La palabra, unidad de lengua, está ausente; la frase, unidad del habla, es soberana" (ápud Castillo Rodríguez, 1988: 49), por lo que el cine vendría a ser un modo de producción carente de unidades como los que tiene la lingüística. Por otro lado, establece para su comprensión tres elementos, el primero de ellos compuesto por los canales de información (imagen, trazos, lenguaje hablado, música y efectos sonoros); el segundo por tres códigos (especificidad, generalidad y reductibilidad); y el tercero por el mensaje. Con respecto a la transposición, sostiene que ocurre a nivel del significado a través de la intervención mediadora de la lengua que ayuda en el pasaje de un código a otro, ya que la lengua es el sistema de signos común, mientras que los signos visuales solo pertenecen al cine ( $c f$. Bermúdez, 2008: 4).

Por su parte, Benveniste (1994) considera a la lengua como un signo privilegiado por su condición de sistema de significancia autónoma a diferencia de otros sistemas significantes como las artes que tienen una significación relativa. "El artista crea así su propia semiótica: instituye sus oposiciones en rasgos que él mismo hace significantes en su orden. De suerte que no recibe un repertorio de signos, reconocidos tales, y tampoco estable ninguno. El color, un material, trae consigo una variedad ilimitada de matices que pasan uno a otro y ninguno de los cuales hallará equivalencia con el 'signo' lingüístico" (ibidem: 11).

Así es como el autor define la no equivalencia sígnica, que al mismo tiempo da lugar a la no equivalencia en las relaciones entre sistemas semióticos que se pueden dar de tres maneras: "de engendramiento", cuando la relación se da entre dos sistemas distintos pero de igual naturaleza, por ejemplo: la lengua usual que engendra la formalización lógico-matemática; "de homología", cuando dos sistemas son de naturaleza diferente; y finalmente, "de interpretancia", en la que otorga preeminencia a la lengua y la constituye como el sistema interpretante de todos los demás sistemas porque posee doble significación, semiótica y semántica (ibídem: 13).

Geoffrey Wagner presenta una clasificación en la que define a la "transposición" como una adaptación fiel o con mínimas diferencias; luego, el "comentario" como una adaptación que parte de una interpretación que hace el realizador de la novela original y que por lo tanto introduce diferencias; y finalmente, la "analogía" que es el resultado de una obra distinta a la original (ápud Carbajal, 2011: 48). Mientras que para Brian Mcfarlane las adaptaciones se dan en dos instancias, el de la transferencia o "plano de cercanía" que tiene a la obra literaria como base; y el de la adaptación o "plano de lejanía” (ibídem: 49).

\section{Las novelas de Jane Austen en el cine}

Las novelas de Austen son tan vigentes aún cuando en su tiempo la novelista inglesa (nacida en la localidad de Hampshire en 1775) no era parte de la moda literaria y más bien gozó de la minúscula acogida de un público pequeño que no alcanzó a retribuirla 
lo suficiente ( $c f$. Valverde, 2008: 11). Era hija de un ministro anglicano rural y pasó la mayor parte de su vida en dicho entorno, el que analizaría con especial talento y agudeza ocupándose de las diferencias de clase entre los individuos que la componían y sus más recurrentes aspiraciones en la vida, entre ellas (como la más relevante), el matrimonio. Este sería el punto de quiebre que haría de Austen una novelista de trascendencia y reconocimiento en las generaciones futuras.

Pese a ello no se podría catalogar a Jane Austen como una escritora romántica ni mucho menos "rosa". Poco valorada por la crítica de su tiempo, no se tardó en reconocer su importancia en los temas que abordaba, los cuales tejidos con la fuerza estilística y argumental de su pluma, harían de sus personajes y sus mundos, universos inmortales. Así pues, más allá de la historia de amor, Austen presenta la situación de la mujer en un mundo de dominio masculino para la que el matrimonio significaba más que la conquista de un amor idealizado, el aseguramiento de un porvenir digno; razón por la que muchas de ellas optaban por casarse por conveniencia tal como le ocurre a algunos personajes de sus novelas. Su temática y su cautivador estilo (crítico, satírico, cerebral y agudo) la colocarían en el lugar que tiene en la literatura universal.

En su primera novela, Amor y Amistad, que escribió a la edad de 15 años, ya se vislumbraba su calidad literaria y sutil ironía. Luego seguirían Northanger Abbey (1817), Sentido y sensibilidad (1811) y Orgullo y prejuicio (1813), novelas que corresponderían a su primera época y que resultarían ser las más conocidas y célebres. Luego vendrían Mansfield Park (1814), Emma (1816) y Persuasión (1817). La primera etapa de mayor viveza argumental y la segunda, aunque "menos propicia a la popularidad, más magistral en su análisis de los caracteres, más hábil en los entramados de las situaciones y más humana en las soluciones finales" (ibídem: 12).

El impacto del cine como medio de comunicación de masas impulsó el reconocimiento de la autora inglesa a nivel mundial y también en el mundo hispano. Las adaptaciones comenzaron en las primeras décadas del siglo XX como es el caso del programa de la $B B C$ "Orgullo y prejuicio" (1938) y de la serie norteamericana "Philco Television Playhouse" de la $N B C$, que incluyó el episodio "Orgullo y prejuicio" en 1949. La $B B C$ vuelve a realizar otra adaptación (en formato de miniserie) de Orgullo y prejuicio en los años de 1952, 1958 y 1967. No obstante, las adaptaciones proliferaron en la segunda mitad del siglo XX. En 1995 la $B B C$ realizó una nueva miniserie de seis episodios de Orgullo y prejuicio con la participación estelar de Jennifer Ehle y Colin Firth, considerada la mejor adaptación de todas las novelas de Jane Austen hasta la actualidad (cf. Jane Austen en castellano, 2015).

Todas sus novelas fueron numerosas veces adaptadas especialmente a la televisión y también al cine; tal es el caso de Sensatez y sentimientos (1994) llevada a la pantalla grande por el director Ang Lee (con guión de Emma Thompson), protagonizada por esta misma, Kate Winslet, Alan Rickman y Hugh Grant, muy apreciada por la crítica y ganadora del Óscar a mejor guión adaptado (ibidem). 
En 2001 se estrenó El diario de Bridget Jones, basada en la novela homónima de Helen Fielding, quien a su vez se inspiró en la novela Orgullo y prejuicio de Jane Austen. Estas adaptaciones dieron pie a que nuevamente tomara impulso otra sucesión de las mismas. En 2005 se estrena otra versión de Orgullo y prejuicio dirigida por Joe Wright, protagonizada por Matthew MacFadyen y Keira Knightley, quien ganó el Óscar a mejor actriz. Esta versión fue acogida favorablemente por la crítica, aunque los expertos en Austen la consideraron insuficiente ( $c f$. Belinchón, 2013). En 2012, las adaptaciones de las novelas de Jane Austen abordaron el mundo virtual con The Lizzy Bennet diaries, la primera serie en YouTube ganadora de los Premios Emmy en 2013 (cf. Pemberley Digital, 2015).

\subsection{Del libro a la película: Orgullo y prejuicio}

Desde las primeras décadas del cine han sido numerosas las adaptaciones audiovisuales de las novelas de Jane Austen. En este trabajo se ha optado por el análisis de la transposición cinematográfica más reciente de Orgullo y prejuicio (2005) dirigida por Joe Wright y protagonizada por Keira Knightley y Matthew Macfadyen. "Posee una fotografía extraordinaria y una puesta en escena magnífica. Los escenarios y diálogos son verosímiles, se crea la atmósfera de la época, se delinean perfectamente los personajes y las actuaciones son de primer nivel" (Rebatta, 2015).

De acuerdo con la clasificación de Wagner (ápud Carbajal, 2011: 48) la versión cinematográfica de 2005 sería una transposición porque la novela se proyecta con un mínimo de interferencias, pero en términos generales con fidelidad a la obra literaria. El punto de partida aquí será detectar las características de esas interferencias que constituyen el aporte del director. De manera más explícita y en términos de Genette (1989) se dirá también que la película es un hipertexto cuya derivación se dio por una relación entre el hipertexto (película) e hipotexto (libro) de transformación, ya que si bien comprende modificaciones, conserva la misma trama con fidelidad, ubicándose en la línea del régimen serio por lo que resulta una transposición. Mcfarlane, por su parte, sugiere como modelo la transferencia o plano de cercanía, si hay proximidad con la obra base, y en este caso como en la mayoría de las adaptaciones de esta novela, la cercanía es evidente desde el título de la película.

Es preciso destacar (desde el principio) los elementos que distinguen a Wright en su reconstrucción. No se puede partir sin hacer referencia al estilo liviano de su narración y a la depuración sencilla de sus diálogos, sin que por ello disminuya la calidad de los mismos. La prevalencia del tono sepia-metálico de los fotogramas, la reiterada y periódica utilización de profundidad en contraste con el plano medio o primer plano en algunas escenas, así como la aportación de celeridad y movimiento de los planos secuencia en alternancia con las escenas (sin desplazamiento) de los personajes (pero en las que resaltan los diálogos o los encuadres y angulaciones) son sus más destacados aportes.

Asimismo, es también parte de esas características propias una tendencia a la brevedad o resumen de ciertos episodios de la novela que en la película se presentan apenas como 
guiños, con el propósito de evitar el vacío que podría desorientar al espectador, pero sin profundizar en ellos. Esto contrasta, por ejemplo, con la adaptación a miniserie que realizó la $B B C$ en 1995 que comprendió 6 episodios: suficiente espacio temporal para poder expresar (con mayor amplitud y nitidez) el perfil de los personajes, sus temperamentos y cualidades muy bien caracterizados por el elenco artístico.

\subsection{El libro y la película}

Dottori (1979: 6), enfatiza que "la ironía de Jane Austen resulta un elemento fundamental de equilibrio; si bien no es directamente enjuiciadora de la sociedad, lo es de una manera menos explícita a través de la crítica que formula a determinados personajes", por lo que el punto de análisis recaería en descubrir si en cada nueva adaptación cinematográfica de una novela de Austen se consigue superar el carácter romántico de la historia, apuntándose más allá al transmitir con particular fuerza creadora la ironía de la autora en el tratamiento argumental. Ello, sin duda, se podrá analizar en la interpretación de algunos elementos claves de la versión fílmica de 2005.

El libro, dividido en dos tomos, consta de 51 capítulos. Comienza con la provocadora frase: "Es una verdad universalmente conocida que al hombre soltero, poseedor de fortuna cuantiosa, le hace falta casarse" (Austen, 1979: 7) que manifiesta, de manera inmediata, el espíritu satírico de la autora que con sutil picardía inicia la narración de la historia entablando desde la primera línea una desentendida complicidad con el lector.

En la versión realizada por la $B B C$ (1995), la miniserie inicia con un solitario paseo de Elizabeth por las campiñas aledañas a su casa: en la medida en que se va acercando oye los griteríos de sus hermanas menores. Risueña e impaciente, se asoma a la ventana de la biblioteca de su padre con quien intercambia unos gestos de complicidad y desaprobación por los gritos de las niñas. La actitud madura, crítica y (al mismo tiempo) complaciente de la protagonista (que deja en claro estar por encima de las discusiones infantiles de sus hermanas) traza las primeras líneas de Austen frente a lo que estaba a punto de contar: crítica pero complaciente al fin, porque quizá dichas ansiedades e intereses de los hombres y mujeres de su época no dejaban de ser cómicas, a pesar de lo trágicas que podían ser.

En el caso de la versión cinematográfica de 2005, Elizabeth Bennet también pasea por las campiñas aledañas a su casa con un libro abierto entre sus manos. Antes de entrar al hogar, contempla desde afuera (a través de una de las ventanas de su casa) a sus padres que conversan vivamente. En este caso, la actitud no es de la que mira todo aquello por encima, sino desde un ángulo más cercano, encontrándose (a fin de cuentas) en no tan diferente condición que sus parientes. Es este el punto de partida de Wright para denotar un tratamiento liviano y orientado a exaltar la historia romántica por encima de otros aspectos considerados en la novela y también en anteriores versiones.

Por otro lado, aplicándose el análisis de las relaciones triádicas de Pierce, se puede también advertir en las primeras líneas del libro que la novela de Austen es un "representamen" 
de una realidad a la que ella busca ajustarse, añadiéndole las libres pinceladas de un ligero tratamiento satírico. Este nuevo signo será el objeto inmediato que (a su vez) dará lugar a un signo equivalente supuestamente más desarrollado, que vendría a ser el film de Joe Wright. Otro análisis de este mismo proceso semiótico partiría de la novela como “objeto representado", la película como "signo" y el "interpretante", el análisis que aquí se procesa o todo signo creado en la mente de los receptores.

La novela pronto inicia los diálogos entre los personajes. En este caso, entre la señora Bennet y su marido, al que aquella informa con ansiedad de la llegada de un caballero afortunado y casamentero a vivir en una propiedad cercana a la suya. El interés en tal acontecimiento radica en las posibilidades de matrimonio para alguna de sus hijas que esa proximidad supone. Con ello enseguida la autora saca a la luz el interés premeditado de la señora Bennet ( sin disimulos ni evasivas) de encontrar marido a sus hijas e ironiza en consecuencia de la actitud, carácter y razonamientos de las mujeres de su tiempo. El personaje que asumirá esa ironía será el propio señor Bennet (quien repetidas veces a lo largo de la novela) se reirá de su propia mujer y sus disparatados juicios. Ahora bien, esa extraña elección de la autora de presentar a la madre de familia con semejante fijación tiene su explicación en la realidad misma que la escritora experimentó, por lo que (según las categorías de la experiencia de Pierce) esta correspondería al "orden de la segundidad", ya que solo será posible entender estos detalles de la trama en función de los datos biográficos de su autora.

En la película de Wright, una vez que Elizabeth entra en su casa, inicia el famoso diálogo entre marido y mujer (lúdico para el padre, angustioso para la madre) aunque no de manera depurada, sino sencilla, pero que comunica con fidelidad la misma situación descrita en el libro. En la versión cinematográfica, muy pronto se inicia el primer baile en el que tiene lugar el encuentro entre el señor Bingley, sus hermanas, su mejor amigo y toda la familia Bennet. La versión de Wright propone un gran salón de baile con numerosos invitados, a los que se suman el señor Bingley y compañía: los mismos que al hacer su arribo paralizan el ambiente festivo cual si de una comitiva real se tratara. En dicha escena, el director enfatiza el estatus social de dichos invitados, muy por encima de los que arribaron antes. Con ese efecto, se incita a una sutil comparación con el príncipe azul de algún cuento de hadas.

La descripción en escenas de los acontecimientos y personajes se da en gran medida de la misma manera armónica, equilibrada (aunque no precisamente intensa) como la autora de la novela, respetándose los escenarios de la época y los modales refinados de sus personajes, aunque más acordes con los tiempos actuales. En cuanto a la intensidad, aparecen episodios en los que apenas se denota el dramatismo (como se verá más adelante) o, por el contrario, se añade una fuerte dosis romántica como sucede con el diálogo de los protagonistas en la escena final (figura 1): 
Figura 1: Secuencia final de la película Orgullo y prejuicio.
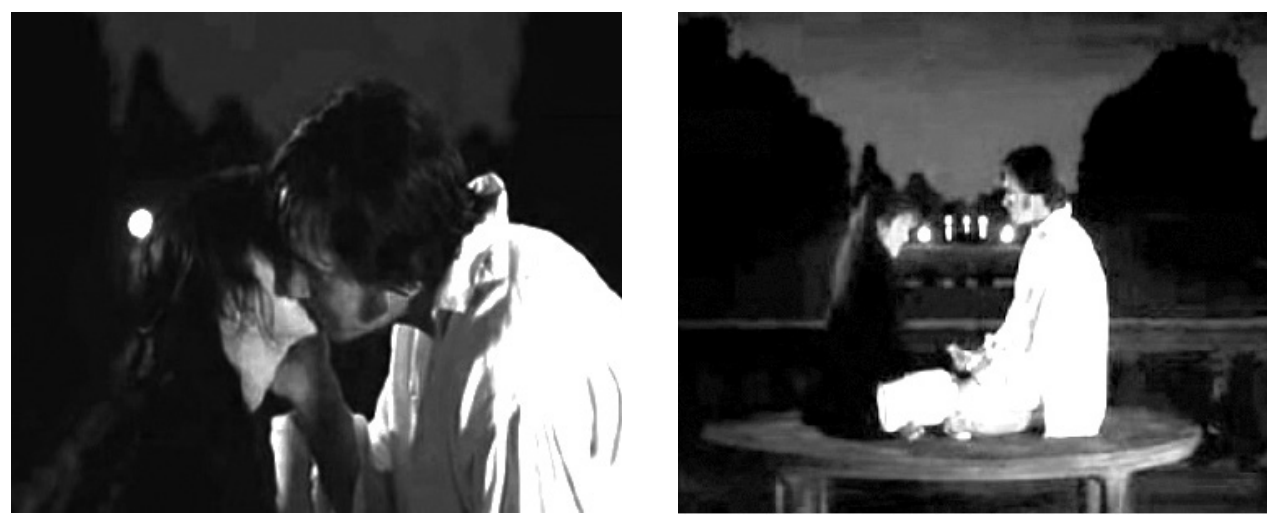

Fuente: Wright (2005).

“-¿Cómo estás hoy, querida?

-Muy bien; pero desearía que no me digas querida.

-¿Por qué?

-Porque es como le decía mi padre a mi madre cuando estaba de malas.

- ¿Cómo quieres que te llame en voz alta?

-Déjame pensar: Lizzie, todos los días, mi amor para algunos días y divina diosa para ocasiones muy especiales.

-Y... ¿cómo debo decirte si estoy de malas?... ¿señora Darcy?

-No, no... Sólo puedes decirme señora Darcy, cuando estés completamente, perfectamente, radiantemente feliz.

-¿Cómo esta noche... señora Darcy?... Señora Darcy, señora Darcy, señora Darcy, señora Darcy..."

En la novela, Austen tampoco presenta la boda y más bien dedica las últimas páginas a dar parte de cómo la noticia fue acogida por los distintos personajes; $y$ a prever el trato cotidiano entre la familia y los yernos como nuevos integrantes en sus reuniones habituales. En esas páginas tiene lugar también una conversación entre Darcy y Elizabeth, en el que ella se muestra acuciosa y sagaz o como la misma autora señala: "Volvió Isabel a ser la chica juguetona de siempre, y quiso que el señor Darcy le contase cuándo se había enamorado de ella" (Austen, 1979: 311); lejos de una cenicienta romántica y enamorada (muy cerebral y no por ello menos tierna) expone sus argumentos:

“-Mi belleza te dejó frío al principio: de mi comportamiento contigo, no hablemos, porque anduvo bordeando la grosería, y siempre que te dirigí la palabra lo hice más bien con la intención de mortificarte. Sé franco... ¿me admiraste por mi descaro?

-Por tu alegría y travesura, sí.

-Dilo sin rodeos; por mi descaro. Si no lo fue le anduvo cerca. La verdad es que tú estabas hastiado de amabilidades, condescendencias y oficiosidades. 
Te asqueaban las mujeres que no tenían más preocupación que buscar el darte gusto con sus palabras, gestos y miradas. Si tú a pesar de las apariencias, no hubieses sido realmente simpático, me habrías tomado aborrecimiento, pero aunque tú te tomabas un gran trabajo en disfrazarte, has sido siempre un hombre de sentimientos nobles y justos; en el fondo de tu corazón experimentabas un verdadero desprecio por las personas que se dedicaban a hacerte la corte tan asiduamente. Yo llamé tu atención y te interesé porque era tan diferente de todas ellas. Ahí lo tienes. Te he ahorrado el trabajo de pensar en ello; bien mirado, esto que yo te digo es perfectamente razonable. Desde luego, cuando te enamoraste no conocías ninguna de mis buenas cualidades...; pero eso mismo les ocurre a todos cuando se enamoran" (ibidem).

\subsection{El análisis}

Basado el análisis en diferentes modelos, esta versión fílmica sería una transposición, lo que no impide que algunos elementos correspondan a la propia interpretación del autor que quedaría asignada como "comentario" de acuerdo a la clasificación de Wagner (ápud Carbajal, 2011: 48). El estilo ligero de la narración apunta al especial realce que el autor da a la historia de amor más allá de otros aspectos que sí contempla la novela, tales como la situación desventajosa de la mujer o los intereses económicos y de clase que resultaban decisivos para avanzar en la vida a fines del siglo XVIII. El propósito de este análisis es identificar algunas de las escenas que correspondan a estas observaciones.

La forma en que Wright pone en marcha la historia se inicia con una acelerada narración de escenas, cuyos espacios, exteriores o interiores combinan los tonos sepia, crepusculares, así como los tonos pálidos y metálicos con la utilización de una cámara subjetiva no precisamente que suplanta al personaje. Si en la novela Austen se consigue la armonía en sus distintas dimensiones, en la película la armonía audiovisual se alcanza con la utilización de planos secuencias intercalados con escenas simples, lo que a su vez dota de dinamismo a la trama. De esta forma, es una película ágil y con tendencia a resumir varios aspectos que sí están considerados en la novela. La movilidad de la cámara en las primeras escenas es prueba de ello: plano secuencia de Elizabeth ingresando a su casa (figura 2), el que exhibe su desplazamiento al interior donde encuentra a sus hermanas, atisbando la conversación de sus padres. 
Figura 2: Primeras escenas de la película Orgullo y prejuicio.
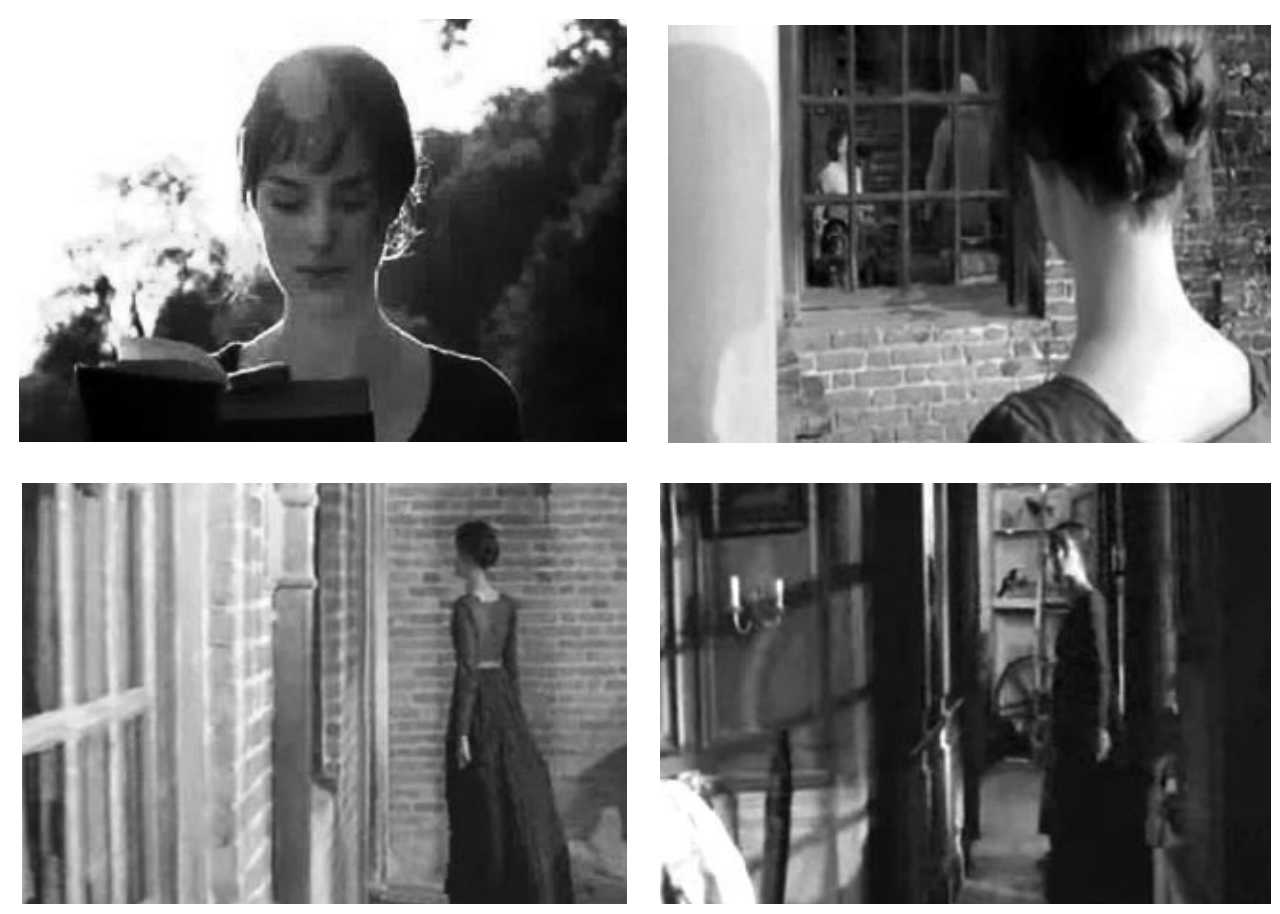

Fuente: Wright (2005).

El encuadre de la protagonista (al lado de una de las ventanas de su casa por la que asoman sus padres conversando) es una técnica reiterativa a lo largo de la película. En este primer caso, ella los observa a través de la ventana y escucha lo que hablan: es el diálogo en el que la señora Bennet informa a su marido de la llegada de un joven soltero y rico. El plano secuencia (en permanente movimiento y cercanía a los personajes) incita a la activa participación del espectador que como un testigo invisible se asoma también a lo que acontece. El plano secuencia continúa con el festejo de las jóvenes cuando escuchan decir al padre que ya ha entablado conversación con el nuevo vecino. Van de un lado a otro, danzan entre ellas, gritan, sonríen, hablan. Elizabeth (la única vestida de marrón) sonríe divertida, sentada en uno de los sofás del salón. El plano secuencia concluye con la técnica capper, efecto de acentuación final con una nota musical.

Otro recurso usado reiterativamente por el director es el plano medio de dos personajes conversando. Es el caso de la escena en la que el señor Collins conversa con la señora Bennet, mientras al fondo se observa el plano general del salón donde están las jóvenes. Lo mismo ocurre con la escena en la que Elizabeth comenta con su amiga Charlotte sobre la presunta atracción mutua entre su hermana y el señor Binbley, observándose al fondo a Binbley de cuerpo entero.

Un ejemplo de ello es también la escena en la que Elizabeth Bennet y su amiga Charlotte conversan; y de pronto, junto a ellas aparecen Darcy y su amigo (figura 3) al que comenta 
que ninguna mujer de la fiesta le parece atractiva y que la señorita Elizabeth tampoco le parece lo suficientemente bonita. Esta situación es especialmente descrita por la autora del libro y representada en la versión de Wright. En este caso, no sólo dos personajes hablan de otros que están presentes, sino que los aludidos también escuchan sus comentarios.

Figura 3: Escenas de la conversación de Darcy con Bingley en la película Orgullo y prejuicio.
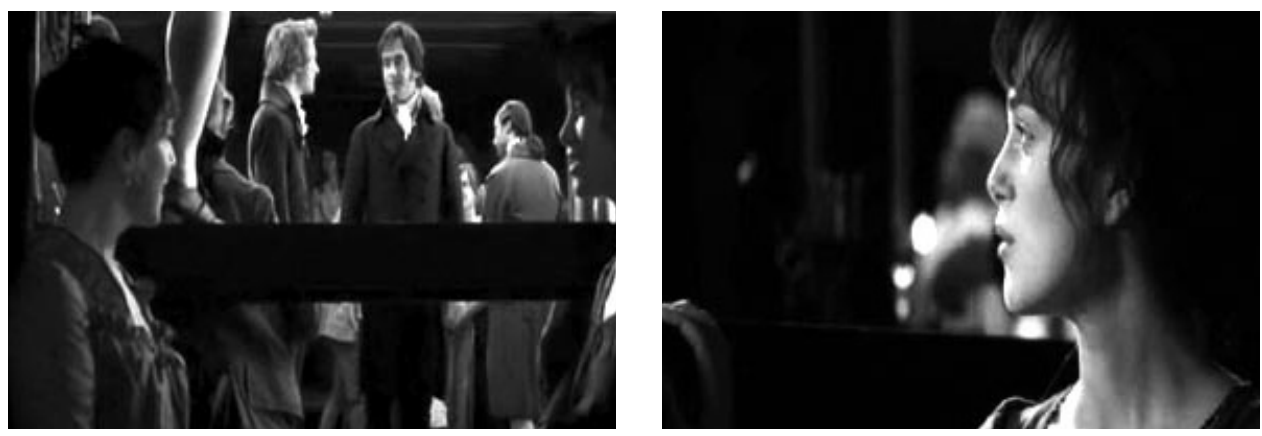

Fuente: Wright (2005).

Otra escena importante es la del baile entre Darcy y Elizabeth Bennet. Esta secuencia presenta dos técnicas narrativas decisivas: la primera de ellas, el efecto de cámara lenta; y la segunda, la descontextualización de la pareja durante breves instantes viéndoseles bailar solos en el enorme salón (figura 4). Por otro lado, la calidad de la atmósfera lograda en escenarios externos (como el del diálogo entre Elizabeth y Wickham, situados debajo de un árbol y junto al río) es similar al de la crítica escena de Elizabeth con sus padres también junto al lago (debajo de un árbol) después de haber rechazado la propuesta matrimonial del señor Collins.

Figura 4: Escenas del baile de Bennet y Darcy de la película Orgullo y prejuicio.
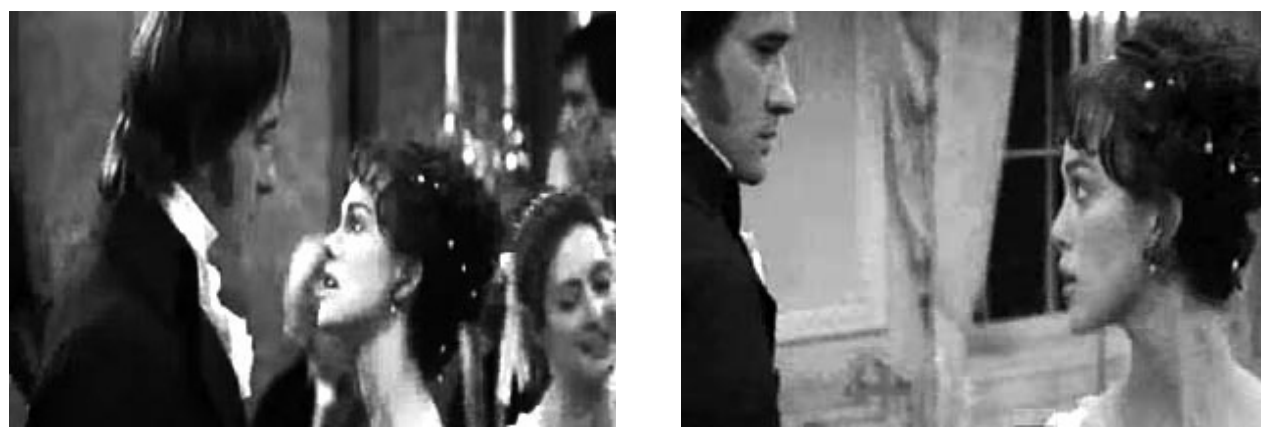

Fuente: Wright (2005).

Ahora bien, con respecto a los diálogos, existen dos momentos en los que se simplifica notoriamente la tensión del suceso. El primero de ellos ocurre cuando Elizabeth llega a 
casa de Binbley en busca de su hermana enferma. Ella (completamente impresentable luego de haber caminado largos trechos bajo la lluvia desde su casa) le produce una mala impresión a la hermana de Binbley, quien murmura críticas contra ella. Se trata de un plano general y otro medio: ella de pie frente a la señorita Binbley y el señor Darcy (figura 5). El silencio prolongado entre los presentes transmite la tensión del encuentro, pero se echa en falta un plano detalle de la ropa húmeda o los zapatos sucios de la recién llegada.

Figura 5: Llegada de Bennet a la casa de los Bingley de la película Orgullo y prejuicio.
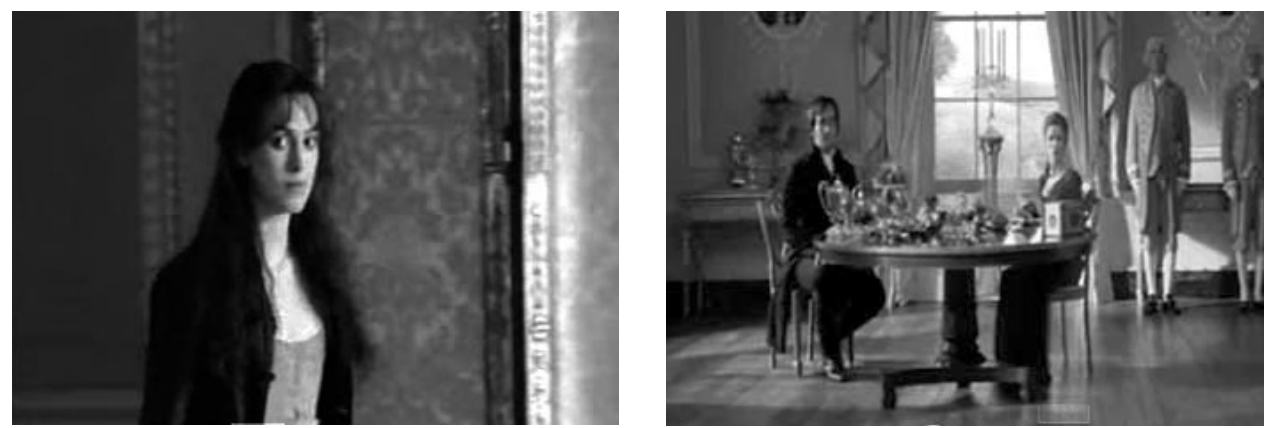

Fuente: Wright (2005).

Lo mismo ocurre con la escena en la que el señor Bennet recibe una carta de su cuñado en la que le informa que Wickham había accedido a casarse con Lidia por una renta de cien libras al año, cosa que sorprende a Elizabeth, encargada de leer la carta a su padre. Caminan desde el carruaje hasta la puerta de su casa, pero el paso acelerado de los personajes resta intensidad a sus reacciones frente a tan sorpresiva noticia. En estos casos, se hace evidente la celeridad y tendencia a la síntesis en la película que disminuye la posibilidad de valorar ampliamente esos sucesos.

El decisivo diálogo de Lady Catherine de Bourgh con Elizabeth Bennet (figura 6) es de los más importantes en la novela y en todas las versiones cinematográficas. En esta versión se hallan algunos cambios. En un momento del encuentro, Lady Catherine exige de Elizabeth la promesa de rechazar a su sobrino si acaso este le propusiera matrimonio. En el libro, la joven rehúye categóricamente hacer esa promesa mientras que en la película sí la hace, aunque después la pareja se sale con la suya. La escena final, tal como se señaló antes, que corresponde a un diálogo entre los enamorados: no se ajusta al libro, sino a una interpretación más del autor que también (como todas las escenas descritas anteriormente) es un rasgo de la categoría “comentario" (ápud Carbajal, 2011: 48). 
Figura 6: Secuencia del encuentro de Lady Catherine de Bourgh y Elizabeth Bennet en Orgullo y prejuicio.
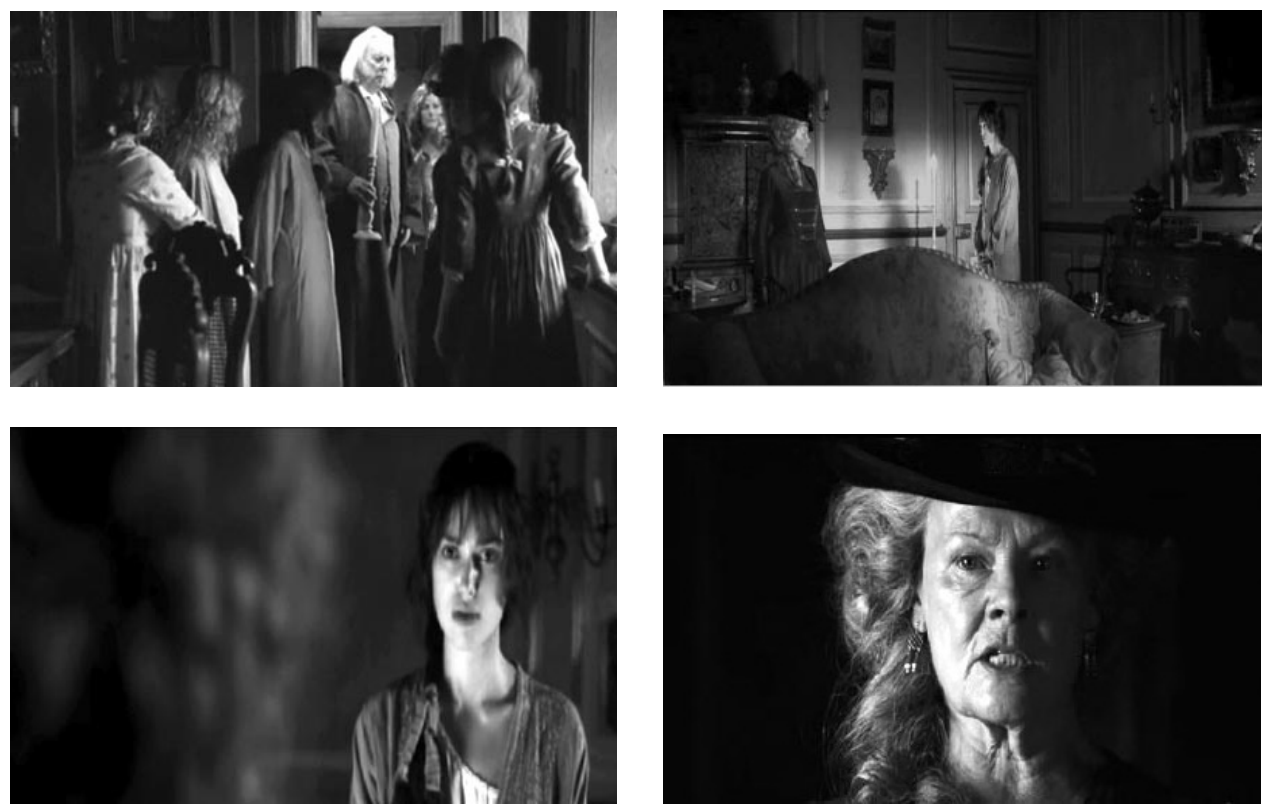

Fuente: Wright (2005).

\subsection{Los personajes}

Los perfiles menos definidos en la película son los de las hijas menores de los Bennet, especialmente María y Lidia, ya que Kitty figura en la novela como seguidora de los gustos y modales de Lidia. Con la lectura previa de la novela resulta entonces más sencillo reconocer a Lidia como la chica problemática cuyo papel es clave en la novela; y a María como la más seria y formal de todas. Por otro lado, resulta impecable el perfil logrado de Lady Catherine de Bourg, como la representación del orgullo y abolengo llevado al ridículo; también es destacable la interpretación de la señora Bennet que personifica el ingenio vulgar y desmedido de algunas personas de ese contexto. En esa misma dirección está situada la figura del señor Collins, aunque diseñado en la película con menos arribismo que en la novela. Todos ellos como puntos conductores de la intención irónica de la autora.

En este análisis se ha intentado destacar las escenas y técnicas narrativas que corresponderían al mínimo de interferencias que supone una transposición y, entre ellas, algunas excepcionales propuestas por el propio director, que corresponderían más bien a la condición de "comentario", según la clasificación de Wagner (ápud Carbajal, 2011: 48). A partir de ello, es posible concluir y ver con claridad que es en ese mínimo de transferencias e interpretaciones del autor donde radica la esencia de la nueva versión, el brillo del estilo del realizador y, en suma, la riqueza de una adaptación. 


\section{C. S. Lewis en el cine}

Es uno de los escritores que goza de especial popularidad por Las crónicas de Narnia, saga literaria compuesta de 7 novelas protagonizadas por cuatro jóvenes que tienen el poder de transportarse a un mundo oculto y paralelo llamado Narnia en el que viven diferentes aventuras entre seres mitológicos, animales parlantes, príncipes y brujas. De todas ellas fueron llevadas al cine El león, la bruja y el ropero (2005), El príncipe Caspian (2008) y La travesía del viajero del alba (2010).

Su vasta producción comprende ensayos tales como El gran divorcio (1945), Mero Cristianismo (1943), Los cuatro amores (1960), entre otros. Nacido en Irlanda en 1898, C. S. Lewis, fue profesor de Literatura en la Universidad de Oxford y Cambridge. En 1955 publicó Sorprendido por la Alegría (1955), un perfil de sus primeros años, que escribió con el fin de dar respuesta a cómo fue su paso del ateísmo al cristianismo, "el libro tiene el propósito de contar la historia de mi conversión y no es una autobiografía general, menos aún 'Confesiones' como las de San Agustín o Rousseau” (Lewis, 1994: 13). Su conversión al cristianismo marcó su labor intelectual; fue miembro del grupo académico vinculado a la Universidad de Oxford ("Inklings") al que también pertenecía J. R. R. Tolkien, con quien tenía una profunda amistad. A él dedicó su obra Cartas del diablo a su sobrino (1940).

En 1993 Richard Attenborough lleva al cine Tierra de Sombras, película basada en el ensayo Una pena observada (1961) compendio de las anotaciones que realizara el autor durante el duelo por la trágica pérdida de su esposa, muerta por un repentino cáncer. La película se centra en el tema del dolor que al mismo tiempo envuelve su relación de amistad y amor con la poetisa norteamericana Helen Joy Gresham.

\subsection{Del libro a la película: Una pena observada y Tierra de sombras}

¿Cómo fue posible llevar al cine un cuaderno de anotaciones? El camino recorrido de un punto a otro es de lo que trata este trabajo con el análisis de la transposición del libro Una pena observada, llevado al cine en 1993 por el director Richard Attenborough, bajo el nombre de Tierra de sombras, con las actuaciones de Anthony Hopkins y Debra Winger.

El proceso dio lugar a una compleja transposición que a partir de un núcleo común resultaron dos productos diferentes. Si bien toda transposición entraña una complejidad por tratarse de la traslación de contenido de un lenguaje a otro, no cabe duda de que la novela y el teatro ofrecen más herramientas que cualquier otro género literario para la realización de una película; empero, en este caso, la naturaleza del libro lejos de ser una novela, comprendía apenas un cuaderno de reflexiones en torno al sufrimiento de su autor, rico en contenido introspectivo, pero pobre en descripciones de tiempos-espacios y personajes que puedan ser dispuestos dentro de una trama.

Ahora bien, ¿de qué recursos se valió entonces el director para narrar en imágenes el dolor que tan profundamente describió C. S. Lewis en sus anotaciones? Todo apunta a que 
Attenborough optó por la historia de amor del escritor como punto central, a cuyo alrededor situó el contenido del libro con la utilización de elementos que este no supo proporcionarle directamente, salvo el prólogo en el que se encuentran pistas y pormenores de una realidad implícita y solo percibida entre líneas a lo largo de sus páginas. Es preciso acotar que en este caso no habría habido dolor sin amor. C.S. Lewis sufre por la ausencia de su esposa y esto es claro desde las primeras líneas del libro. Sin embargo, la historia de ese amor fue hallada en diversas fuentes biográficas que hicieron posible la realización de la película. Así se explica también cómo el título de la película fue tomado de uno de los cuentos del autor.

\subsection{El libro y la película}

Una pena observada no es precisamente una novela: es un cuaderno de apuntes hecho libro. Tampoco se trata de un diario, porque lo que motivó al autor a escribir no fueron los detalles de sus vivencias cotidianas en un cuidadoso orden cronológico, sino un sentimiento concreto: la pena por la muerte de su esposa. Douglas Gresham (1997: 7), hijo de Joy Gresham y autor del prólogo, califica al libro como "el producto apasionado de un hombre valiente que encara y examina su agonía". Componer un cuaderno de anotaciones ayudaría a C. S. Lewis a entender el sentido de su pena, a aceptar la ausencia de su amada y conocer un poco más sobre su relación con Dios; más allá de que el solo acto de escribir lo aliviaría.

En Una pena observada no hay escenarios bien descritos, no hay acciones ni fechas y casi tampoco hay interacción entre personajes. Todo gira en torno a unas sensaciones, a unos recuerdos y a una manera de percibir el mundo en medio de una pena; y todo ello demuestra que C. S. Lewis no escribió un "tratado" sobre el dolor, sino de una situación profundamente personal:

"Si se llamara 'La pena observada' su planteamiento podría ser genérico y poco específico, académico y por lo tanto de muy poca utilidad para quien está padeciendo la experiencia del duelo [...] Este libro es el escueto relato de un hombre por dominar y finalmente derrotar la parálisis emocional de la más estremecedora pena de su vida" (Gresham, 1997: 8).

\subsection{Argumento del libro}

La obra consta de cuatro capítulos. En el primero de ellos describe al dolor comparándolo con el miedo y esboza su necesidad de estar rodeado de gente, aunque no tenga la menor motivación de atenderles y prestarles atención. Todo este padecimiento lo empuja a recordar con nostalgia sus días felices, cuando todavía no conocía a la que sería su esposa. Reclama la presencia de Dios y cuestiona el hecho de su aparente ausencia cuando más lo necesita. Considera que el matrimonio le sirvió de ayuda para descubrir que el amor no es un sustituto de Dios, sino que son la misma cosa. Medita el impacto que causó en los niños la muerte de su madre y cuenta el sentimiento de absoluto rechazo que les produce hablar de ella. Vuelve la mirada hacia la enfermedad de su mujer, que también terminó con la vida de sus padres. 
En el segundo capítulo se siente abrumado al notar que por todo lo anterior ya escrito, pareciera que la importancia de la muerte de $\mathrm{H}^{8}$ estaba en el dolor que le causaba no verla y no en ella misma. Así es como empieza a describirla y resalta sus enormes ganas de vivir. Uno de los puntos más cruciales de sus cavilaciones es cuando se cuestiona la firmeza y legitimidad de su fe: "Nunca sabes cuánto crees verdaderamente en algo, hasta que su verdad o falsedad se te vuelve asunto de vida o muerte" (Lewis, 1997: 36), y luego encuentra que la ayuda que da la religión no es de ninguna manera la del consuelo, ya que creer que ella está con Dios no le alivia la pena ni le libra de su ausencia.

En el tercer capítulo persiste la añoranza. Aún sin estar pensando en ella en cada instante, siente que todas las cosas están impregnadas de una sensación de desorden, de error y de que sucede algo malo y es cuando recuerda que ella no está más. A estas alturas se da un cambio evolutivo en su interior, en tanto que intenta ser más racional y busca dar una mirada mucho más objetiva a las cosas. Esto se manifiesta en el reconocimiento de la fragilidad de su fe, a la que llama una "casa de naipes" endeble y reconoce que la muerte de $\mathrm{H}$ ha introducido un nuevo factor en su comprensión del Universo.

Lewis confiesa que su fe en Dios era parecido a su amor por H y así es como llega al planteamiento de Dios permite el dolor porque no existe otra manera para hacer que el ser humano sea consciente de la inmadurez de su fe. Niega rotundamente la idea de llamarle "prueba" a su experiencia dolorosa, porque Dios no necesita probar nada, ya que Él lo sabe todo. Este sería el punto inicial de su convalecencia, incluso llega a percibir que la pena apasionada no le acerca a los muertos, sino que lo aparta de ellos.

En el cuarto y último capítulo se manifiesta un Lewis más sereno y maduro. Observa que ya no necesita de más cuadernos para escribir, que aquellos le sirvieron como válvula de escape, pero que ya no los requería. Recuerda que su primera intención fue usar esos cuadernos para describir un estado o diseñar un mapa de la tristeza; sin embargo, concluye en que este es más bien un proceso que no necesita de mapa, sino de una historia. Describe su regreso a los mismos parajes que antes recorrió junto a ella y nota que su mirada es otra, más límpida y nueva.

\subsection{Argumento de la película}

Tierra de sombras es el nombre de la película de Richard Attenborough, en el que Anthony Hopkins encarna al profesor Lewis desde antes de conocer a la poetisa Joy, interpretada por la actriz Debra Winger. El escritor C. S. Lewis recibe cartas de sus lectores y entre ellas la recurrente correspondencia de Helen Joy Gresham, una poetisa norteamericana, asidua lectora de sus libros, que tiene en sus miras ir a Londres, por lo que le propone un encuentro.

8 Así es como la menciona a lo largo del texto, con la letra inicial de su primer nombre Helen Joy Gresham. 
La cita se concreta y no tardan en hacerse buenos amigos. Pasa el tiempo y a su regreso por segunda vez a Inglaterra, la poetisa decide quedarse en Londres y es cuando por razones prácticas y con el fin de ayudarla, Lewis decide casarse civil con ella, pues con esto Joy conseguiría la radicación inglesa. Aquella unión carecía de especial significado para ambos por lo que lo consideraban un "matrimonio técnico".

Un día, sorpresivamente, Joy cae enferma y no se recupera más: le diagnostican cáncer a los huesos. A estas alturas, aquella amistad se había transformado en amor que (muy a su pesar y demasiado tarde) Lewis tuvo que reconocer. Poco tiempo después le pide la mano para contraer matrimonio religioso. La lenta agonía de Joy es el clímax de la historia, momento en el que ambos atraviesan una profunda crisis que desborda de sus corazones con una serie de cuestionamientos que Lewis sólo podrá responderse mucho después de la muerte de su esposa.

\subsection{El análisis}

La película pudo empezar con la muerte de la esposa (que es el punto originario de la existencia del libro). Sin embargo, Attenborough opta por otorgarle un marco referencial a dicho suceso y lo enmarca con una sucesión de hechos biográficos (que desde el inicio y de manera progresiva) contribuyen a una fácil comprensión de la historia. Va de lo general a lo particular; primero, ubica al protagonista en el espacio laboral, la universidad, en el que reconstruye escenarios, sucesos, personajes. Luego lo ubica en su casa, donde vive tranquilamente con su hermano Warnie, soltero como él; estas escenas son un preámbulo del decisivo encuentro entre C. S. Lewis y Joy Gresham.

Wagner (ápud Carbajal, 2011: 48) con respecto a la fidelidad en la traslación de una obra de un soporte a otro, considera tres modelos: a) el de "transposición", en el que apenas hay diferencias entre una obra y otra; $b$ ) el de "comentario", que es la interpretación propia del realizador; y c) el de "analogía", que lleva a cabo una obra de arte distinta. En este caso, se trataría de un comentario, dado que el director brinda un giro biográfico a Una pena observada dándole, sin que por ello deje de ser central el episodio de dolor vivido por C. S. Lewis.

El film empieza con una ceremonia religiosa (figura 7) realizada en la Universidad de Oxford a inicios de la década de 1950. Luego siguen las escenas de un cotidiano regreso a casa de Lewis en compañía de su hermano, dos adultos solteros sin preocupaciones ajenas al mundo intelectual. En ese instante aparece en pantalla el acuse en texto de que se trata de una historia real, sobre una escena de noche azul en la que los hermanos van camino a casa. La niebla es una característica permanente en las escenas de interiores y exteriores, así como el tono sepia de las imágenes. 
Figura 7: Primeras escenas de la película Tierra de sombras.
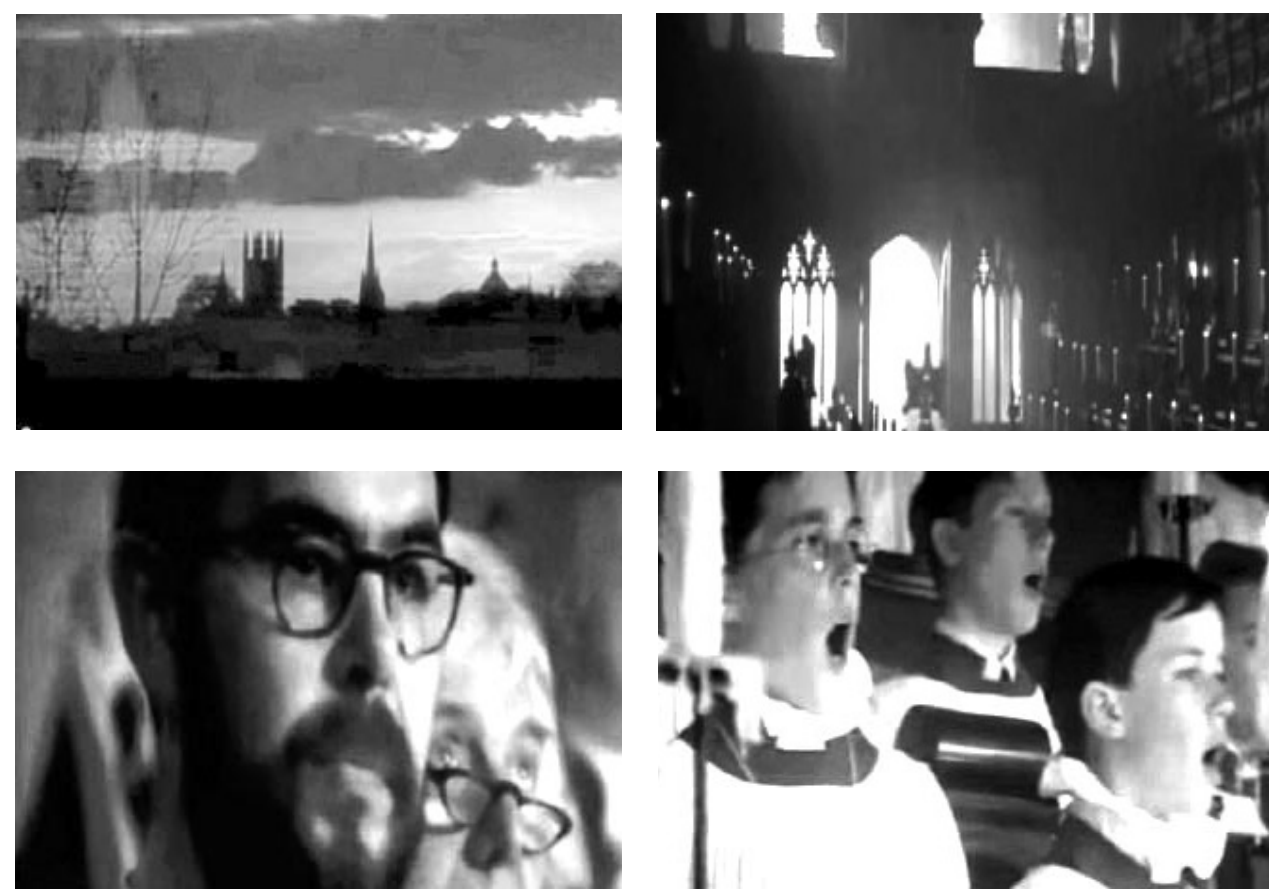

Fuente: Attenborough (1993).

Los planos secuencias de la vida habitual del profesor sirven de preámbulo del acontecimiento decisivo de la historia (el encuentro entre Jack y Joy) y para ayudar a entender al espectador la magnitud del amor entre ambos y, en consecuencia, el hondo dolor cuando acaeció la pérdida, pues como menciona Gresham (1997: 10), "si queremos comprender algo del agudo dolor que contiene este libro, y el coraje que demuestra, antes debemos reconocer ese amor"; de otro modo, la reproducción cinematográfica hubiera quedado relegada a lo meramente subjetivo: una historia melodramática, convencional e imposibilitada de expresar su dimensión real.

La película parte de un ensayo, género que prescinde de muchos elementos de la narrativa. Ahora bien, según las relaciones triádicas de ejecución de Pierce, Una pena observada sería un "índice", que refiere directamente a algo real, el dolor que siente C. S. Lewis por la muerte de su esposa, pero que es preciso conocer más a fondo. Para conseguir ese propósito, el prólogo es el elemento clave para el desarrollo de la trama cinematográfica. El prólogo se presenta como el argumento que explica las dimensiones reales que permanecen implícitas en las reflexiones de C.S. Lewis, por lo que se constituye como el argumento perteneciente al orden de la terceridad, según las relaciones triádicas de pensamiento de Pierce (1974: 31).

Las reflexiones claves del libro son puestas en escena a través de diálogos y monólogos a lo largo de la trama así como otros aspectos tomados de la biografía de C. S. Lewis. 
El director de la película les otorga un interlocutor, un espacio y un tiempo a su debido momento. De ahí que este es un "comentario" según Wagner (ápud Carbajal, 2011: 48), y más aún si se consideran los nombres diferentes de libro y película. Desde la perspectiva de Mcfarlane (ibídem: 49), esta sería una transferencia por ubicarse en el plano de la cercanía, ya que tanto en el libro como en la película, el dolor es el tema central. Una escena que precisa de la interpretación propia del director, por ejemplo, en este caso para que el propio protagonista haga referencia directa al nombre de la película es el diálogo que C. S. Lewis tiene con su alumno Peter Whistler (figura 8).

Figura 8: Jack conversa con Peter Whistler en la película Tierra de sombras.
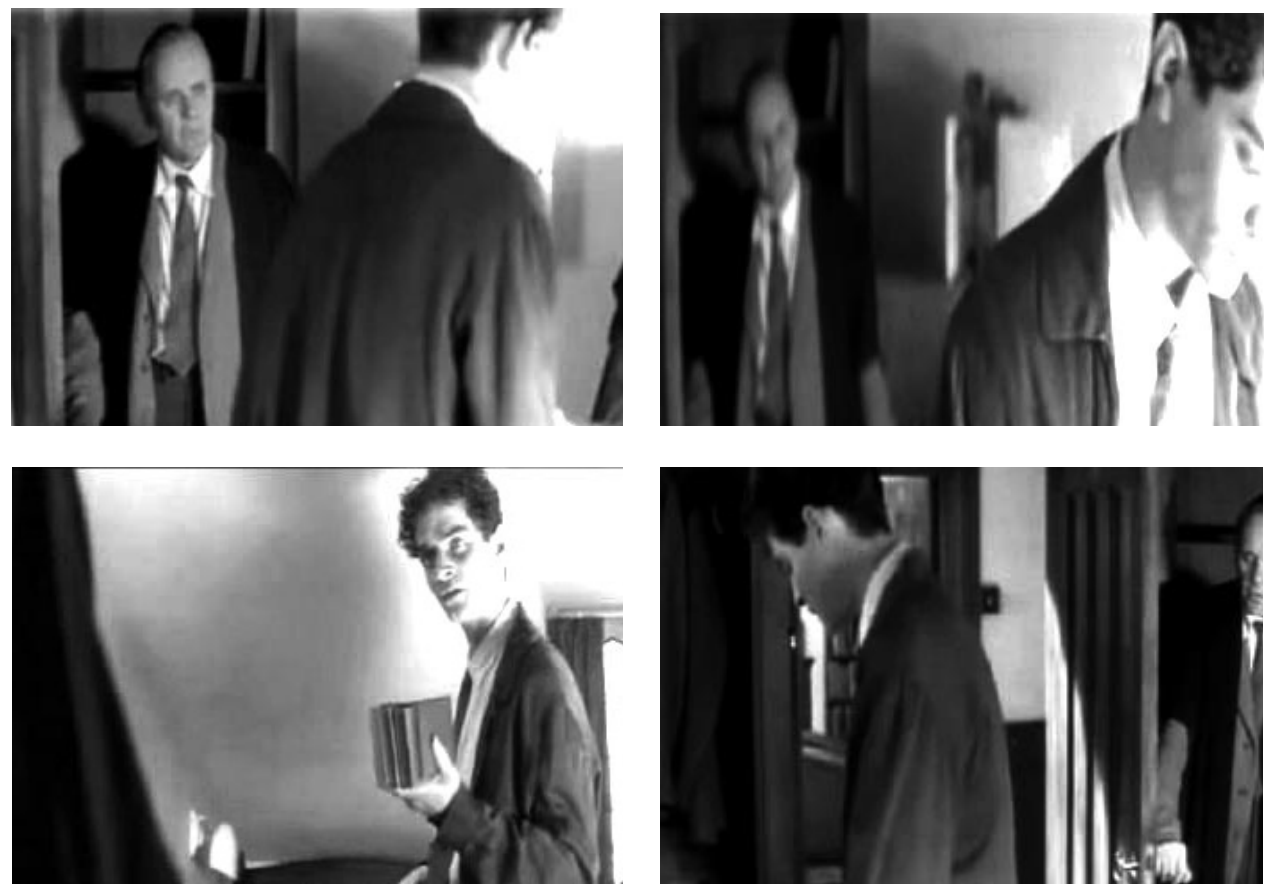

Fuente: Attenborough (1993).

“-¿Qué? ¿Se va?... ¿A dónde? -pregunta C. S. Lewis al alumno.

- A Londres.

-¿Por qué? ¿Es por dinero?

-En realidad, no.

-Un año más y se habría graduado.

-Sí, ¿y luego qué?, ¿a enseñar, como usted?

-Me pregunto qué es lo que quieren todos de mí.

-Es la primera vez que le oigo preguntar algo como si no supiera la respuesta.

-Ah... ¿y eso es bueno?, ¿eso es lo que quiere?, ¿ignorancia, confusión?

-Sencillamente no creo ver mi futuro tan claro como lo ve usted.

- Sombras... 
-¿Qué?

-Es uno de mis cuentos... Vivimos en tierra de sombras. El sol siempre brilla en otra parte, más allá de la curva, más allá de una colina”.

El punto culminante de la escena es cuando el alumno se detiene para mirarlo, un plano medio lo enfoca con unos libros en la mano, en el que él le manifiesta su asombro porque es la primera vez que le oye preguntar sin saber la respuesta. Antes de este encuentro, él había tenido una conversación con Joy en la que le reprochaba la forma en que había organizado su vida para que nadie lo toque: todos eran mayores que él, todos lo estimaban, ganaba todas las discusiones, etc.; por lo que C. S. Lewis reflexiona sobre la imposibilidad de comprender a los demás y así mismo. Otro momento importante que reconstruye Attenborough para poner en los labios de C. S. Lewis las reflexiones del libro es la escena en la que C. S. Lewis repentinamente se encuentra con dos de sus amigos que le preguntan por la salud de su esposa:

“-Jack, ¿alguna novedad?

-Sí, creo que hay buenas noticias, Harry.

-Me alegro mucho, Jack.

- Gracias Christopher, gracias.

-Christopher podrá burlarse, pero yo sé cuánto has rezado -comenta Harry. -Ja ja.

-Ahora Dios responde a tus plegarias.

-No rezo por eso, Harry; rezo porque no puedo contenerme, rezo porque me siento impotente, rezo porque la necesidad de rezar fluye de mí constantemente... Eso no cambia a Dios, me cambia a mí".

Preocupado desde siempre por los asuntos existenciales, da charlas regulares a la Asociación de Maestros Cristianos y es en las escenas de aquellas conferencias en las muchas veces afirma: "Dios no quiere que seamos felices, sino que seamos amados y sepamos amar. El sufrimiento es el megáfono de Dios para despertarnos, para despertar al mundo sordo". Como se puede observar, esas alteraciones permiten una comprensión profunda de la trama y especialmente de las reflexiones del dolor que escribe C. S. Lewis en el libro, que solo con el uso de esos recursos se pueden comprender audiovisualmente.

Genette (1989: 15) considera dos formas de relación entre hipotexto e hipertexto que pueden ser de transformación o de imitación. La transformación comprende tres tipos de regímenes ${ }^{9}$ : parodia (lúdico), travestimiento (satírico) y transposición (serio). La imitación comprende los regímenes: pastiche (lúdico), imitación satírica (satírico) e imitación seria (serio). Así, la diferencia entre transformación e imitación consiste en que la transformación supone un cambio de estilo pero no de tema; mientras que la imitación supone un cambio de tema pero no de estilo. En Tierra de sombras se dio un cambio estilístico, mas no del tema.

9 Por otro lado, Genette (1989: 42) sustituye el término "función” por el de régimen, "por parecerme un término más flexible y menos drástico, pero sería ingenuo imaginar que se pueda trazar una frontera estanca entre estas grandes diátesis del funcionamiento sociopsicológico del hipertexto". 
La experiencia de dolor por la pérdida de su esposa es el núcleo del libro y de la película. La película enmarca ese suceso dentro de un cuadro biográfico, mientras que el libro sólo gira en torno a la pena que el autor observa en sí mismo. La película pretende contar una historia con la explicación y descripción de escenas y sucesos; el libro no pretende contar nada, sino trazar un mapa de la tristeza que le permita a su autor comprender lo que le sucede y aliviarse. No obstante, no se debe perder de vista que la película no tendría razón de ser sin el libro. La motivación de la realización cinematográfica de ninguna manera fue la biografía de $\mathrm{C}$. $\mathrm{S}$. Lewis, sino la experiencia de dolor del autor acerca de su relación afectiva.

Gresham (1997: 10) advierte que "mucho se ha escrito, mucha ficción y mucho verdadero (y en algunas ocasiones lo uno como si fuera lo otro) acerca de sus vidas, su encuentro y su matrimonio". Por lo que posiblemente Attenborough ha tenido que seleccionar cuidadosamente los detalles de la historia apoyándose en diversas fuentes, incluido el propio Douglas Gresham quien estuvo presente durante el rodaje del film.

El libro refiere la llegada de Joy Gresham a Inglaterra con la intensión de dialogar con Jack acerca de una obra que la autora estaba escribiendo sobre los diez Mandamientos, Humo en la montaña (1954), durante su convalecencia de una seria enfermedad. Sin embargo, en Tierra de Sombras no se explicita esta razón como el motivo principal para que ambos entren en contacto, sino simplemente el interés de la poetisa por conocer al escritor a quien ya había enviado muchas postales con anterioridad (figura 9).

Figura 9: Primera cita entre Jack y Joy Gresham en la película Tierra de sombras.
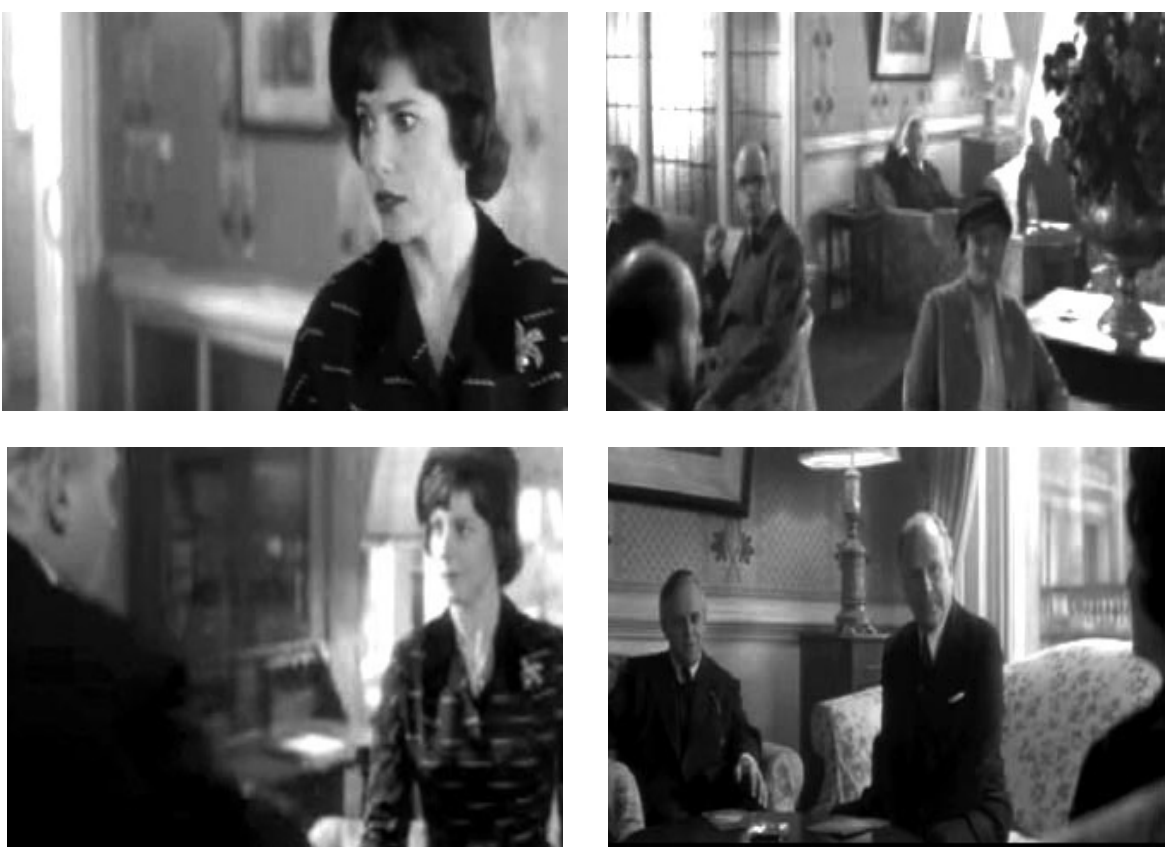

Fuente: Attenborough (1993). 
La segunda visita tuvo lugar en casa del autor, donde dialogan sobre los poemas de Joy: ella recita para él uno de ellos, "Nieve en Madrid"; mas no hubo escena alguna en que hablaran sobre el libro que estaba escribiendo ni tampoco sobre los cuestionamientos que ella tenía sobre la fe y que necesitaba aclarar con Lewis; aunque sí se da a conocer su formación comunista y su posterior conversión al cristianismo en las escenas del primer encuentro.

Joy Gresham realiza dos viajes a Inglaterra. Durante su primera visita conoce a Lewis y permanece poco tiempo en Inglaterra; la segunda vez va para quedarse definitivamente luego de haber puesto fin a su matrimonio con el novelista W. L. Gresham. La escena que narra este hecho es en la que ella intenta aclarar porqué impidió que su hijo llamara por teléfono a su padre la noche de Navidad; y confiesa que salió huyendo porque sus relaciones con su marido eran muy violentas y ya habían terminado.

Figura 10: Matrimonio civil de Jack y Joy en Tierra de sombras.
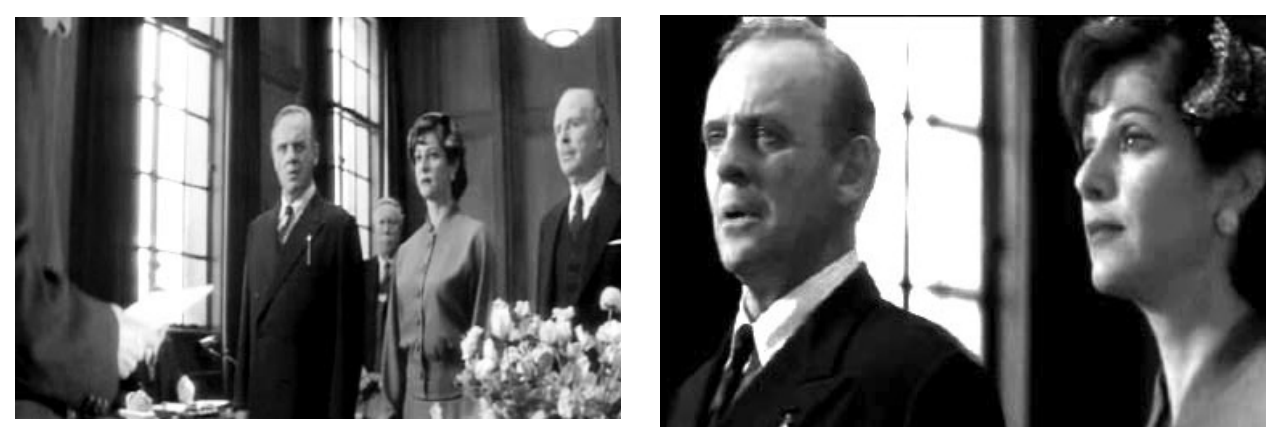

Fuente: Attenborough (1993).

El libro no menciona nada sobre el matrimonio civil que prematuramente unió a Joy y Jack, al que ambos llamaban "matrimonio técnico" en el film, con la única finalidad de que ella obtuviera la radicación inglesa. De hecho, se trata de una escena bastante natural y práctica en el que los involucrados guardan estrictamente las distancias: el hecho que no hubiera anillo de boda dejaron claras sus verdaderas intenciones, ni mucho menos explica sobre cómo después ellos llegan a casarse por amor (figura 10).

La aceptación de ese enlace se basaba en la clara diferencia que encontraban ambos entre el matrimonio civil y el religioso; y así lo explica C. S. Lewis en la escena en la que da la noticia a su hermano Warnie: "Un verdadero matrimonio es una declaración ante Dios no ante un funcionario del gobierno" (figura 11). 
Figura 11: Conversación de Jack y Warnie en Tierra de sombras.
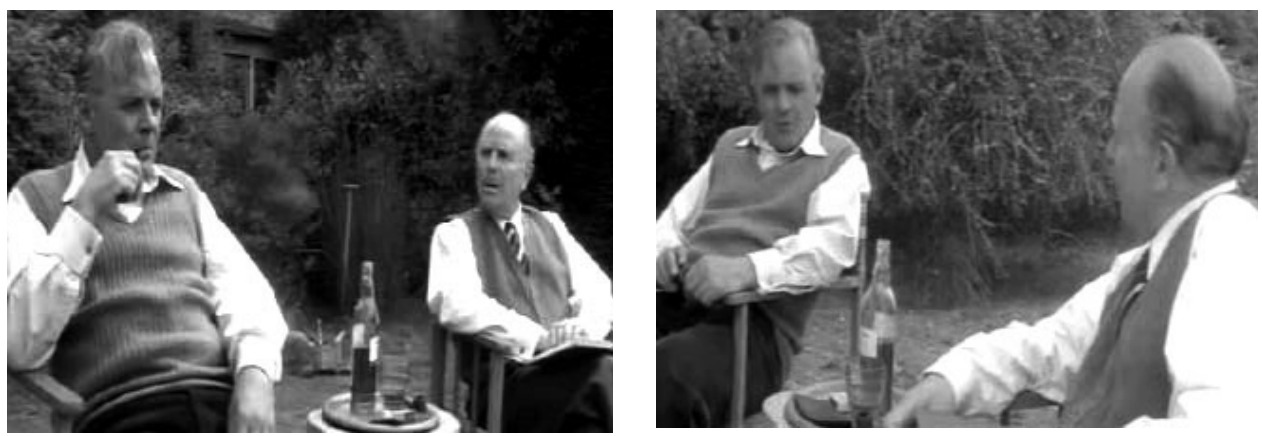

Fuente: Attenborough (1993).

La escena de la boda es una de las más conmovedoras del filme, en la que Joy postrada en una cama del hospital da el sí definitivo a Jack en presencia del celebrante anglicano, del hijo de la novia y Warnie, hermano de Jack (figura 12). Es en ese preciso instante en el que se desencadena el sufrimiento de ambos: días felices en un instante de recuperación, paseos por los prados, momentos compartidos, pero con pesar porque temen lo que se avecina. En la película la vida matrimonial se limita a unos meses; en la vida real esa unión duró cuatro años (cf. Guzzetti, 2013).

Figura 12: Matrimonio religioso de Jack y Joy en Tierra de sombras.
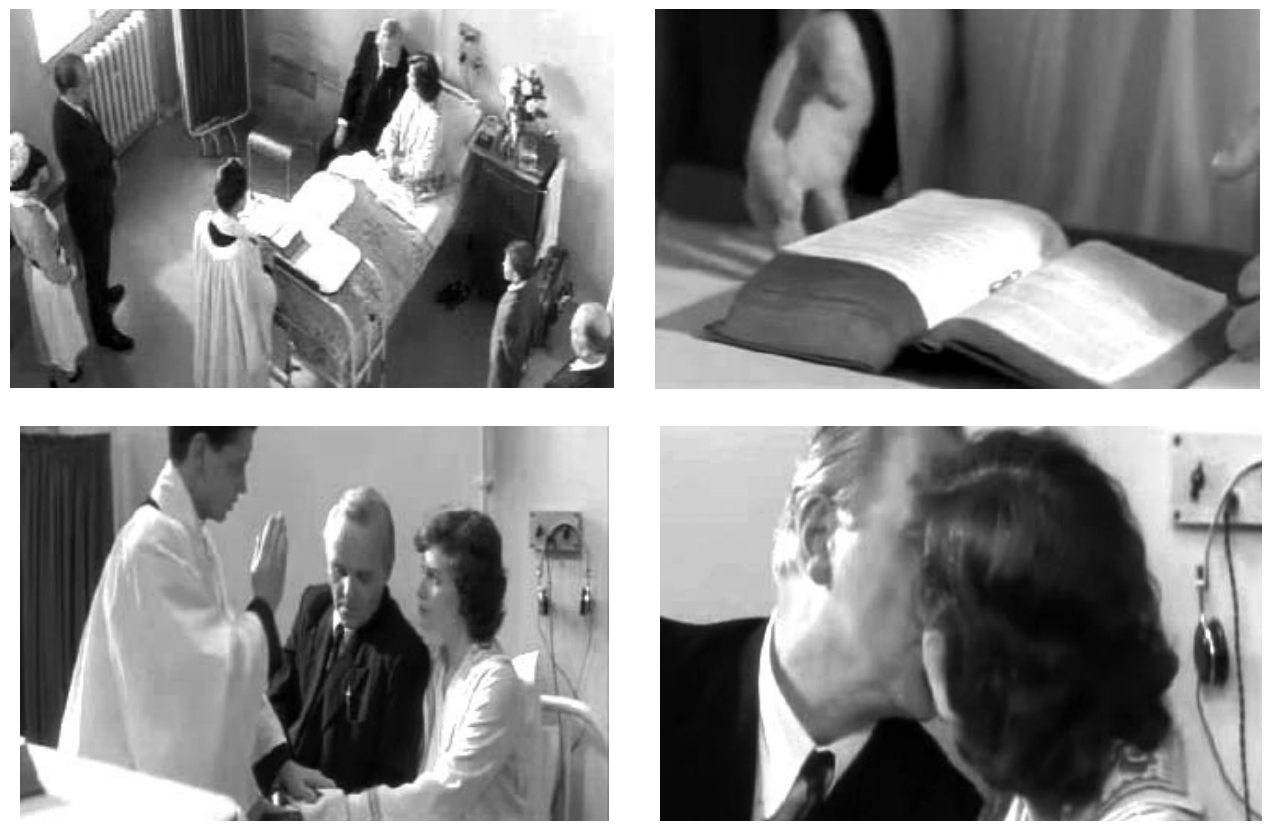

Fuente: Attenborough (1993). 
Las escenas finales (tras la muerte de Joy) transparentan un renacimiento interior del escritor, quien luego de no poder entender el dolor, la ausencia del ser amado y la muerte, se siente suficientemente preparado para salir otra vez al encuentro de la vida, de las cosas y lugares que recorrió junto a su esposa y que sin ella antes le causaban dolor, como es el caso del Valle Dorado en Herefordshire, que C. S. Lewis consideraba el paraíso cuando era niño y del que conservaba un cuadro en su habitación, que llamó la atención de Joy, a quien durante el tiempo de su temporal restablecimiento le propuso ir a conocer.

Figura 13: Escena final de la película Tierra de sombras.

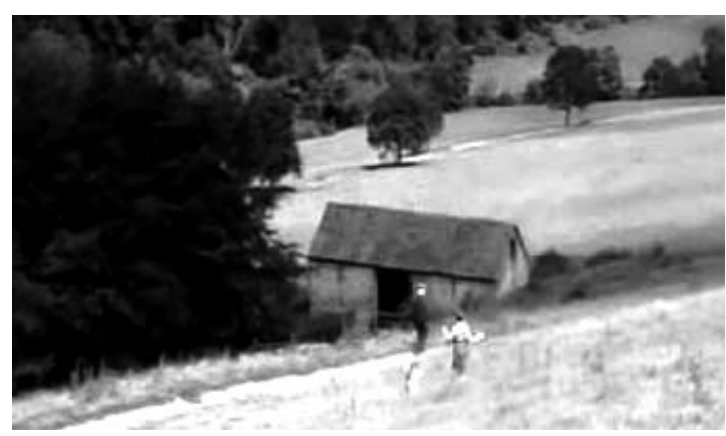

Fuente: Attenborough (1993).

En las últimas escenas, Lewis recorre los mismos parajes paisajísticos en los que estuvo acompañado con Joy: praderas y campos reverdecidos, que al mismo tiempo representaban la imagen de felicidad para ambos. En el libro se menciona su reencuentro con esos parajes como muestra de su recuperación. En la película recorre ese ambiente sin temor y con libertad, junto con su hijastro y un perro que los acompaña, mientras una voz en off revela sus pensamientos definitivos: “¿Por qué amar si la pérdida duele tanto? Ya no tengo más respuestas, sólo la vida que he vivido. Dos veces en esta vida me dieron a elegir, como niño y como hombre. El niño eligió la seguridad y el hombre eligió el sufrimiento. La pena de ahora es parte de la felicidad de entonces" (figura 13).

\subsection{Los personajes}

\subsubsection{Helen Joy Gresham "H"}

En el libro, este personaje principal está muerto. En todo caso, su ausencia es palpable y es el centro de las meditaciones de Lewis. De ella no hay ninguna intervención directa, todas son referencias acerca de las cosas que hizo $\mathrm{H}$, que es como él la llama en sus escritos, sobre las decisiones que tomó, actitudes suyas y algunos rasgos de su personalidad. Otra alternativa de realización fílmica podría haber partido de la ausencia de ella y de remembranzas a base de sucesivos flashbacks; no obstante, el director Attenborough permite que Gresham se dé a conocer por sí misma, según las ingentes referencias del autor del libro acerca de ella, así como a partir de los testimonios de su hijo. 


\subsubsection{L. Lewis "Jack"}

"Jack era un hombre cuya extraordinaria erudición y capacidad intelectual lo aislaba de gran parte de la humanidad" (Gresham, 1994: 9), describe Douglas a su padrastro Clive Staples Lewis, quien gustaba que le llamaran Jack. Lewis tenía 54 años cuando conoció a Helen Joy Gresham, mucho más joven que él y vivía con su hermano Warnie H. Lewis. Aquella extraordinaria erudición y dedicada vida intelectual hicieron de él un hombre inaccesible, que lo mantuvo al margen de cultivar amistades profundas. Es este aspecto de su personalidad que reprocha Joy en la película, cuando se sorprende de la forma en la que había organizado su vida para que "nadie lo toque".

\subsubsection{Douglas Gresham}

Joy Gresham tuvo dos hijos (David y Douglas). Sin embargo, en la película sólo tiene lugar uno de ellos (Douglas Gresham), quien más adelante sería escritor igual a sus padres (el novelista W. L. Gresham era su padre biológico). En el libro es un jovencito de catorce años, mientras que en la película es apenas un niño de nueve; esto puede atribuirse a que Lewis sufrió la pérdida de su madre a esa edad; por lo que se fusionarían en el niño la figura del hijo de Joy y del propio Lewis.

En el libro, Lewis denuncia haber advertido una actitud de rechazo de parte de los niños cuando él trataba de hablarles sobre su madre fallecida. Este episodio es ilustrado en la película cuando luego de la insistencia de su hermano Warnie, Jack decide conversar con el pequeño que dará lugar a una de las escenas más conmovedoras del film, en el que Lewis llora desconsolado con el niño (figura 14).

"-Cuando mi madre murió yo tenía tu edad. Creía que si rezaba para que se mejorara y si de veras creía... ella se pondría mejor, que no moriría, pero se murió -inicia la conversación Lewis sentándose a lado del abrumado niño.

- No funciona...

-No, no funciona

-No me importa -concluye Douglas.

-Quise muchísimo a tu madre. Quizá la amé demasiado, ella lo sabía. Ella me dijo: Vale la pena, porque sabía lo que pasaría más tarde. No parece justo ¿verdad?...

-No entiendo por qué tenía que enfermarse.

-Yo tampoco, pero no puedes aferrarte a cosas, debes dejarlas ir.

-Jack ¿crees en el Paraíso?

-Sí, creo.

-Yo no creo en el Paraíso.

-Está bien.

-Quisiera volver a verla...

-Yo también...” (lloran). 
Figura 14: Escenas de la conversación de Jack con el pequeño Douglas en Tierra de sombras.
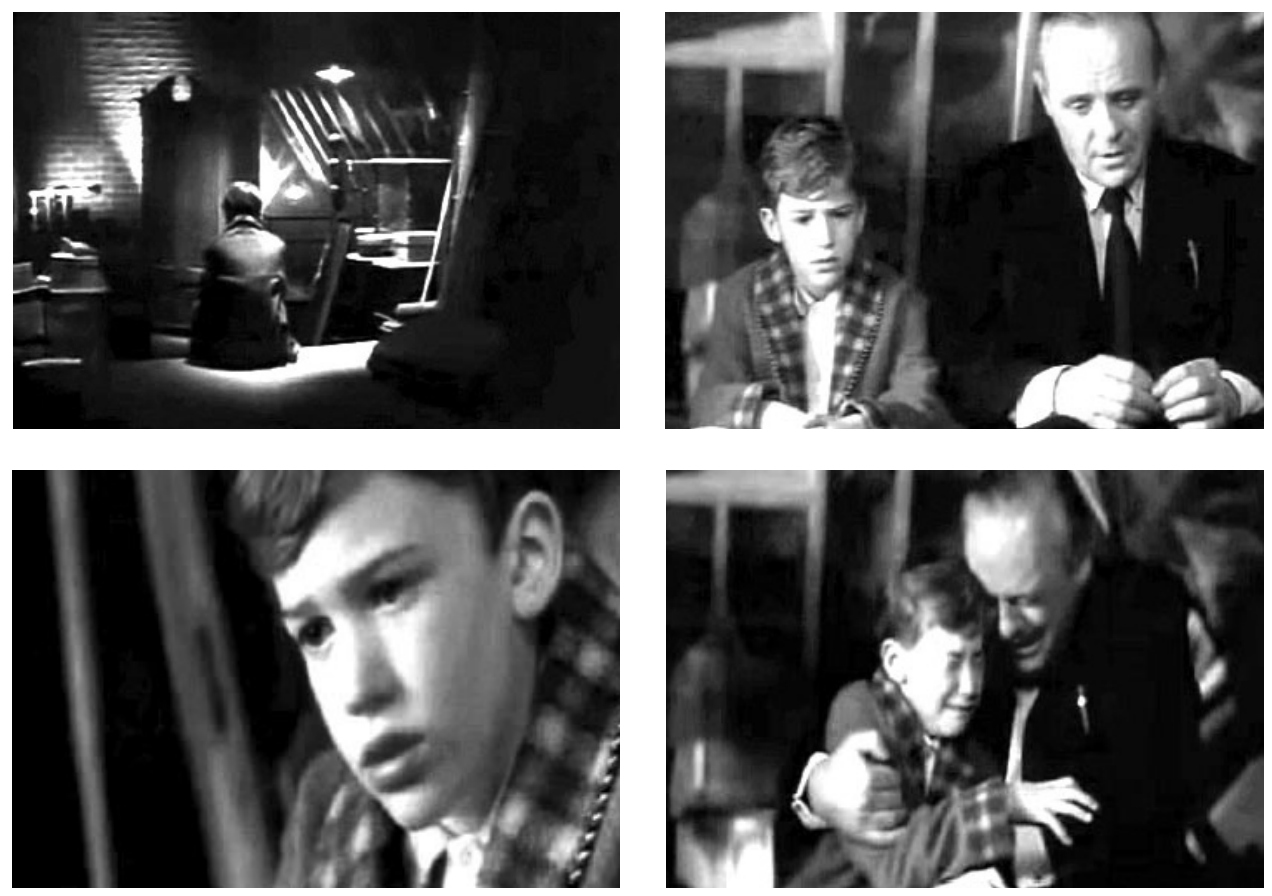

Fuente: Attenborough (1993).

En el prólogo, Gresham aclara que en la sociedad inglesa de esos tiempos estaba mal visto ver llorar a un hombre en público, motivo por el que ellos trataban de evitar toda conversación acerca de su madre, pues sabían que les sería imposible no llorar. "No puedo hablarles a los niños sobre ella. Apenas lo intento, no se les manifiesta en la cara ni pena ni amor ni miedo ni piedad, sino el más fatal de los no conductores, la confusión. Me miran como si estuviera cometiendo una indecencia. Anhelan que me detenga. Me sentía igual yo mismo cuando murió mi madre, y mi padre la mencionaba. No los puedo culpar. Así funcionan los niños" (Lewis, 1997: 22).

\subsubsection{Otros personajes}

Naturalmente el film tiene más personajes que el libro. En la película cobran vida los integrantes del grupo The Inklings: círculo de intelectuales al que pertenecía Jack. En varias escenas se ve que asiste a charlas y diversas reuniones sociales, todos hombres y solteros que muestran increíble sorpresa por la fortuita presencia de la escritora norteamericana en la vida de Lewis. Muy cerca de él está su hermano Warnie (historiador, soltero y escritor como él), su más cercana compañía. Peter Whistler es su pupilo, el cual permite un acercamiento a la faceta académica de Lewis y a su relación con sus alumnos. Varias 
conversaciones determinantes tienen lugar con él, como aquella escena en la que al ser descubierto por llevarse libros sin permiso le dice: "Mi padre decía que leemos para saber que no estamos solos". Frase que conmueve a Lewis.

\section{Los receptores y las adaptaciones fílmicas}

Las obras literarias devienen en la actualidad en nuevas versiones cinematográficas fieles a ellas o sencillamente basadas en algunas de sus características concretas para dar lugar a versiones completamente diferentes. The Lizzy Bennet Diaries es un ejemplo: serie basada en la novela Orgullo y prejuicio realizada para YouTube con la situación de la trama en un contexto completamente contemporáneo. Estas producciones son conseguidas gracias a que la tecnología digital proporciona los medios para prescindir de grandes presupuestos $\mathrm{y}$, en contraste, conseguir amplios márgenes para el desarrollo de ideas originales como aquella, en la que los personajes dialogan entre ellos y también con el espectador, situación en la que resultan innecesarios más escenarios, vestuarios, etc.

Si en los inicios de la sociedad de masas, la literatura devino en literatura por entregas (a través del folletín) y con la invención del cine llegaron muchas de esas obras a la pantalla grande (para dirigirse a un público heterogéneo y mucho más amplio) es deducible que las historias, leyendas y mitos hayan viajado a través de la memoria social y colectiva en diferentes soportes ad infinitum hasta llegar a la aldea global constituida por una tecnología digital. Frente a ello, la cuestión es identificar las pérdidas y mutaciones que se han producido como consecuencia de esas transiciones.

McLuhan afirmó que el medio es el mensaje. A partir de ese razonamiento se podría concluir que en la sociedad contemporánea la poderosa naturaleza de los medios audiovisuales condiciona los contenidos, los trastocan hasta transformarlos totalmente. Frente a ello surge inexorable la inquietud por conocer y deslindar cuáles son los criterios sobre los que los medios audiovisuales se basan para retener algunos elementos, tramas, personajes y dejar pasar otros. Por ejemplo, Jane Austen analizó la sociedad de su tiempo desde una aguda mirada crítica e irónica; no obstante, lo que prevalece de sus obras en la dimensión audiovisual es el romance y las perspicacias humanas para obstaculizarlo o facilitarlo, seguramente porque la búsqueda del amor es un valor humano universal que trasciende toda época y contexto, aunque con ello se arriesgue con los enfoques superficiales de algunas versiones.

Por su parte, Rebatta (2015) sostiene que son dos las circunstancias desde las que las audiencias se aproximan a las adaptaciones cinematográficas. La primera de ellas de quienes han leído la obra literaria y van con curiosidad a comparar las imágenes que concibieron al leer el libro con las imágenes cinematográficas, experiencia que generalmente suscita disconformidad con la película, lejos de comprender el proceso de discriminación en el momento de transponer el contenido de un lenguaje a otro. La otra circunstancia es de quienes (atraídos por la publicidad) ven la película y posiblemente después lean el libro. 
Empero, toda comparación es vana, porque se tratan de dos universos significativos diferentes. Es posible que quienes han leído el libro vayan con una predisposición a encontrar lo que buscan en la adaptación; mientras que los que van a ver primero la película se interesen por el romance, la fantasía o el suspenso como sus géneros favoritos, que al final resultan los más comerciales. Con respecto a ello, sostiene que el cine comercial tiende a buscar la fidelidad de la novela por un fin predecible de taquilla, mientras que motivaciones más artísticas tienden a proponer como base la obra literaria, pero a partir de ella crea algo original y a veces radicalmente distinto.

En suma, el éxito de las adaptaciones en la sociedad digital estaría encaminado por la versatilidad de las creaciones, fácil y rápidamente transformables. Asimismo, por el fortalecimiento de imaginarios sociales como el drama, el amor romántico, el suspenso, pero que para que sean consideradas producciones de calidad, como afirma Rebatta (2015), no deben perder de vista la condensación de la historia en una estructura o escaleta, la conversión de los diálogos escritos en diálogos conversacionales o coloquiales y principalmente pensar en imágenes que se expresen por sí mismas.

\section{Fuentes consultadas}

Attenborough, R. (director) (1993). Tierra de sombras [película]. Londres: Price Entertainment.

Austen, J. (1979). Orgullo y Prejuicio. Buenos Aires: Centro Editor de América Latina S. A.

Belinchón, G. (2013, enero 28). “'Orgullo y Prejuicio', de Jane Austen, más allá de los libros”. En blog Versión muy original. Extraída el 28/VII/2015 desde http://blogs.elpais. com/version-muy-original/2013/01/jane-austen-en-el-cine-y-la-television.html

Benveniste, E. (1994). "Semiología de la lengua. Problemas de Lingüística General II", pp. 47-70. Extraída el 27/VII/2015 desde http:/web.udl.es/usuaris/s2430206/materials/ Benveniste.pdf

Bermúdez, N. (2008). “Aproximaciones al fenómeno de la transposición semiótica: lenguajes dispositivos y géneros”. Estudios semióticos, núm. 4. Extraída el 27/VII/2015 desde http:// www.fflch.usp.br/dl/semiotica/es/eSSe4/2008-eSSe[4]-N.\%20D.\%20BERMUDEZ.pdf

Carvajal, E. (2011). "De lo literario y lo fílmico en Del amor y otros demonios". Acta Literaria, núm. 43. pp. 45-59. Extraída el 10/VII/2015 desde

http://www.redalyc.org/articulo.oa?id=23721471004

Castillo Rodríguez, F. (1988). "El lenguaje cinematográfico”. Semiosis, núm. 21, pp. 4375. Extraída el 27/VII/2015 desde http://cdigital.uv.mx/handle/123456789/6352 
Dottori, N. (1979). "Estudio Preliminar", pp. I-VI. En Austen, J. Orgullo y Prejuicio. Buenos Aires: Centro Editor de América Latina S. A.

Eisenstein, S. (1977). Film form. Essays in Film Theory. San Diego: Harcourt, Inc.

Genette, G. (1989). Palimpsestos. La literatura en segundo grado. Madrid: Taurus.

Gresham, D. (1997). "Un Prólogo a Una pena observada” pp. 7-16 En Lewis, C. S. Una pena observada. Santiago de Chile: Andrés Bello.

Guzzetti, S. (2013, octubre 16). “'Yo y mi padre C. S. Lewis': Douglas Gresham, converso, vela para que Narnia no sea tergiversada". Extraída el 27/VII/2015 desde

http://www.religionenlibertad.com/yo-y-mi-padre-cs-lewis-douglas-gresham-conversovela-para-31621.htm

Jane Austen en castellano (2015). "Las adaptaciones para cine y televisión de la obra de Jane Austen”. Extraída el 27/VII/2015 desde https://janeaustencastellano.wordpress.com/ filmografia/

\section{Lewis, C. S.}

_(1997). Una pena observada. Santiago de Chile: Andrés Bello.

_(1994). Sorprendido por la alegría. Santiago de Chile: Andrés Bello.

Martín-Barbero, J. (1987). De los medios a las mediaciones. Barcelona: Gustavo Gili.

Pemberley Digital (2015). "The Lizzie Bennet diaries". Extraída el 28/VII/2015 desde http://www.pemberleydigital.com/the-lizzie-bennet-diaries/

Peña-Ardid, C. (1999). Literatura y cine. Una aproximación comparativa. Madrid: Cátedra.

Pérez Villarreal, L. (2001). Cine y literatura. Entre la realidad y la imaginación. Quito: Ediciones Abya-Yala.

Pierce, C. (1974). La ciencia de la semiótica. Buenos Aires: Ediciones Nueva Visión.

Rebatta, F. (2015, julio 24). Comunicador y director. Entrevista personal. Lima.

Sánchez Noriega, J. (2001). "Las adaptaciones literarias al cine: un debate permanente". Comunicar, núm. 17. pp. 65-69. Extraída el 20/VII/2015 desde http://www.redalyc.org/articulo.oa?id=15801709

TV Pública Argentina (2013, marzo 11). "Los 7 locos - 09-03-13 (1 de 4)”. Extraída el 18/ VII/ 2015 desde https://www.youtube.com/watch?v=OAR_pNboxB4 
Valverde, J. (2008). "Prólogo", pp. 9-16. En Austen, J. Emma. Barcelona: Lumen, Tusquets Editores.

Wilson, A. (1990). C. S. Lewis. Biografia. Santiago de Chile: Andrés Bello.

Wright J. (director) (2005). Orgullo y Prejuicio [película]. Londres: StudioCanal. 